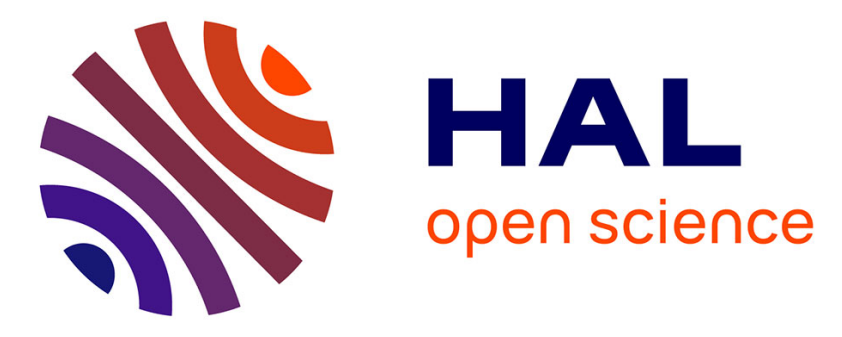

\title{
Study of the spatial and historical distribution of sediment inorganic contamination in the Toulon bay (France)
}

Erwan Tessier, Cédric Garnier, Jean-Ulrich Mullot, Véronique Lenoble, Mireille Arnaud, Michel Raynaud, Stéphane Mounier

\section{To cite this version:}

Erwan Tessier, Cédric Garnier, Jean-Ulrich Mullot, Véronique Lenoble, Mireille Arnaud, et al.. Study of the spatial and historical distribution of sediment inorganic contamination in the Toulon bay (France). Marine Pollution Bulletin, 2011, 62, pp.2075-2086. 10.1016/j.marpolbul.2011.07.022 . hal01096845

\section{HAL Id: hal-01096845 \\ https://hal-univ-tln.archives-ouvertes.fr/hal-01096845}

Submitted on 5 Jan 2015

HAL is a multi-disciplinary open access archive for the deposit and dissemination of scientific research documents, whether they are published or not. The documents may come from teaching and research institutions in France or abroad, or from public or private research centers.
L'archive ouverte pluridisciplinaire HAL, est destinée au dépôt et à la diffusion de documents scientifiques de niveau recherche, publiés ou non, émanant des établissements d'enseignement et de recherche français ou étrangers, des laboratoires publics ou privés. 
Provided for non-commercial research and education use. Not for reproduction, distribution or commercial use.

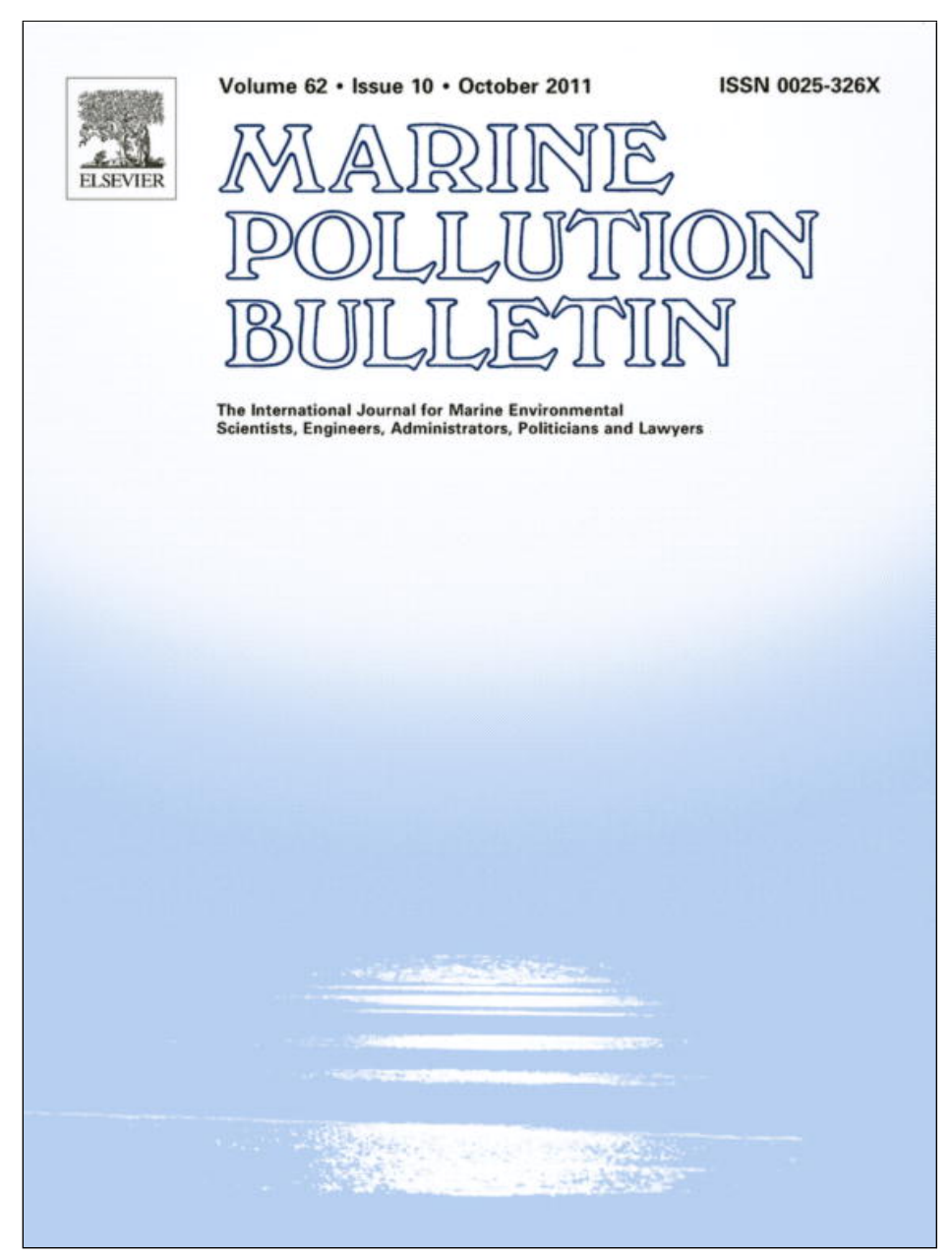

This article appeared in a journal published by Elsevier. The attached copy is furnished to the author for internal non-commercial research and education use, including for instruction at the authors institution and sharing with colleagues.

Other uses, including reproduction and distribution, or selling or licensing copies, or posting to personal, institutional or third party websites are prohibited.

In most cases authors are permitted to post their version of the article (e.g. in Word or Tex form) to their personal website or institutional repository. Authors requiring further information regarding Elsevier's archiving and manuscript policies are encouraged to visit:

http://www.elsevier.com/copyright 


\title{
Study of the spatial and historical distribution of sediment inorganic contamination in the Toulon bay (France)
}

\author{
Erwan Tessier $^{\mathrm{a}, \mathrm{b}}$, Cédric Garnier ${ }^{\mathrm{a}, *}$, Jean-Ulrich Mullot $^{\mathrm{b}}$, Véronique Lenoble ${ }^{\mathrm{a}}$, Mireille Arnaud ${ }^{\mathrm{c}}$, \\ Michel Raynaud $^{a}$, Stéphane Mounier ${ }^{a}$ \\ a Laboratoire PROTEE, Université du Sud Toulon-Var, BP 20132, 83957 La Garde, France \\ ${ }^{\mathrm{b}}$ LASEM-Toulon, Base Navale De Toulon, BP 61, 83800 Toulon, France

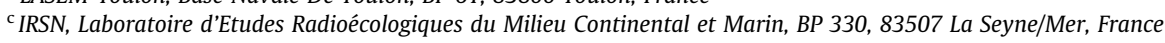

\section{A R T I C L E I N F O}

\section{Keywords:}

Sediment contamination

Metals

Toulon bay

Surface cartography

Depth profile

\begin{abstract}
A B S T R A C T
This study presents trace elements levels in surface and deep sediments of the Toulon bay (SE France) subjected to anthropogenic inputs (navy base, harbors, etc.). The studied elements ( $\mathrm{As}, \mathrm{Cd}, \mathrm{Cr}, \mathrm{Cu}, \mathrm{Hg}, \mathrm{Ni}, \mathrm{Pb}, \mathrm{Zn}$ ) are defined as priority contaminants in aquatic systems. Fifty-five points scattered on the entire bay were sampled, allowing the determination of contaminants distribution with a high resolution. Several approaches were used to assess the degree of contamination and the potential toxicity of the Toulon bay sediments: comparison to the French legislation, surface-weighted average metal concentrations, enrichment factors (EF), geoaccumulation indices (Igeo), trace element stock calculation and comparison to sediment quality guidelines. A principal component analysis was performed to reveal common behavior of the studied contaminants. Results demonstrated the very high contamination of the small bay, especially in $\mathrm{Hg}$ (EF up to 1500), $\mathrm{Cu}, \mathrm{Pb}$ and $\mathrm{Zn}$, with export to the large bay further governed by hydrodynamics.
\end{abstract}

(c) 2011 Elsevier Ltd. All rights reserved.

\section{Introduction}

The exponential development of human activities during the last century has caused a negative impact on all environmental compartments, including aquatic environments. Among the many pollutants used by humans, heavy metals constitute a major source of contamination. Metals are introduced into the water column under different forms: particulate, colloidal and dissolved (Kennish, 2002). Once in the water column, metals are quickly adsorbed onto particles, deposited and accumulated in sediments, which therefore act as a sink for these contaminants. However numerous studies have demonstrated that sediments are not only a sink but also a possible source of contamination to the water column due to desorption and remobilization processes (Saulnier and Mucci, 2000; Zoumis et al., 2001; Kim et al., 2006; Tankere-Muller et al., 2007; Kalnejais et al., 2010). Therefore the evaluation of metal distribution in surface sediments is the first step to assess the degree of pollution of a marine environment (Cosma et al., 1979; Bertolotto et al., 2005; Sprovieri et al., 2007; Martín et al., 2009).

The present study concerns Toulon bay (SE France), a semiclosed Mediterranean area, separated in two parts by a sea wall, submitted to various anthropogenic inputs, particularly nautical

\footnotetext{
* Corresponding author. Tel.: +33 494142099; fax: +33 494142168.

E-mail address: cgarnier@univ-tln.fr (C. Garnier).
}

activities (marina, industry, Navy). Because of this separation and the absence of regular freshwater inputs, associated to low tide, circulation of water in the small part of the bay is limited, leading to low water regeneration and so possibly high contaminant accumulation in sediments. To maintain navigational depth, harbors' dredging is currently regularly required but must respect the current legislation. Assessment of sediment contamination and toxicity is critical to preserve the environment during dredging operations. For this reason, Toulon bay is the subject of an intensive investigation of its sediment contamination, in the framework of a multi-partner collaborative project ("Contrat de baie Rade de Toulon"), to respond to criteria defined by the Water Framework Directive of the European Community.

In this work, surface spatial distributions and depth profiles of the eight trace elements identified as priority contaminants in aquatic systems (i.e. As, $\mathrm{Cd}, \mathrm{Cr}, \mathrm{Cu}, \mathrm{Hg}, \mathrm{Ni}, \mathrm{Pb}$ and $\mathrm{Zn}$; European Community Water Framework Directive 2000/60/EC; Anonymous, 2000) were characterized in core sediments collected from the whole bay to evaluate the contamination level resulting from anthropogenic inputs. Surface spatial distribution reflects recent inputs while depth profiles are the signature of historical contamination.

The environmental sediment quality was discussed in comparison to the $N 1$ and $N 2$ levels defined by the French legislation on marine and estuarine sediment dredging (JORF No. 184, 10-082000). To assess the degree of sediment contamination and to distinguish natural and anthropogenic inputs, metal-enrichment 
factors (EF) (Hilton et al., 1985; Ergin et al., 1991; GuerraGarcía and García-Gómez, 2005; Cukrov et al., 2011) and geoaccumulation indices (Igeo) were calculated (Müller, 1979; Buccolieri et al., 2006; Ji et al., 2008). Based on the metal concentrations measured in surface and deep sediments, trace element stocks calculations were performed. Statistical analyses (PCA) have been carried out to establish a common origin and/or behavior of the contaminants (Kähkönen et al., 1997; Reid and Spencer, 2009; Passos et al., 2010). From this analysis the potential risk on benthic organisms was estimated using ecotoxicological indices (Long et al., 1995, 1998; USEPA, 2005).

\section{Study area}

Located on the French NW Mediterranean coast, Toulon is a large urban area of approximately 600,000 inhabitants. Toulon bay is divided in two non-equal parts, a small part $\left(9.8 \mathrm{~km}^{2}\right.$, semi-enclosed) submitted to various anthropogenic inputs (French Navy, commercial traffic, raw sewage of urban area, industry) and a large part (42.2 $\mathrm{km}^{2}$ ), less impacted and open to the sea (Fig. 1). The small bay is the final gathering place of the town catchment area streaming. Low tides in the Mediterranean Sea associated with weak currents in the Toulon bay have significant implications on the contaminants accumulation in sediments.

\section{Materials and methods}

\subsection{Sampling}

Surface sediment sampling campaigns were conducted in November 2008, February and June 2009, with the help of French Navy boat and material, allowing the sampling of surface sediment cores (Interface Corer, Plexiglas ${ }^{\circledR}$ tube, $10 \mathrm{~cm}$ diameter and $1 \mathrm{~m}$ long) preserving the water/sediment interface integrity. Fifty-five points were sampled (Fig. 1), in duplicate, covering the entire bay. For some shallow points, sampling was performed by navy scuba-divers. A differential global positioning system (DGPS) was used to precisely identify each location.

For each surface site, both sampled cores were sliced (0-5 and $5-10 \mathrm{~cm}$ ), pooled and homogenized (with a Teflon spoon), then placed into pre-cleaned $1 \mathrm{~L}$ high-density polyethylene (HDPE) bottles and deep frozen $\left(-18{ }^{\circ} \mathrm{C}\right)$. Additionally, a small amount was placed in scintillation vials and kept refrigerated at $4{ }^{\circ} \mathrm{C}$ until the granulometry measurement. All frozen samples were subsequently freeze-dried (at a maximum of one month after) and sieved (2 mm).

To trace the metal contamination history, additional interface cores were sampled (in duplicate) and sliced every $2 \mathrm{~cm}$ under

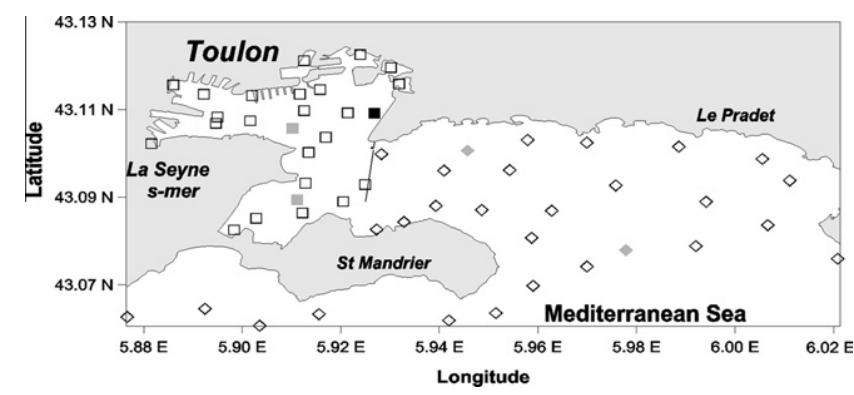

Fig. 1. Map of the sampling sites in the Toulon bay (SE France). Square/diamond symbols are used to differentiate samples from small/large part of the Bay; open/ closed symbols distinguished surface sediments $(0-5$ and $5-10 \mathrm{~cm}$ slices) from deep cores (sliced every $2 \mathrm{~cm}$ ); black square symbol corresponds to the site selected for deep contaminant profiles depicted in this paper. nitrogen conditions. The same treatment protocol as described above was used on each obtained slice.

\subsection{Sediment analysis}

Sediment particle size distribution was determined from $1 \mathrm{~g}$ of fresh sediments (in triplicate) using a laser diffraction particle-size analyzer (LS 13320 BECKMAN COULTER ${ }^{\circledR}$ ) with multi-wavelength technology called polarization intensity differential scattering (PIDS) enabling a better accuracy of clay fractions. Fresh sediments were placed in $50 \mathrm{~mL}$ plastic tubes and diluted with water to obtain a concentration close to $10 \mathrm{~g} \mathrm{~L}^{-1}$. Ten millilitre of these solutions were analyzed in triplicate with the laser grain sizer (Marion et al., 2010). The range of analysis was $0.4-2000 \mu \mathrm{m}$ (in 117 fractions) with an accuracy of 3\% for median size and $5 \%$ for each size of the distribution profile. The $<63 \mu \mathrm{m}$ fraction was calculated by summing the clays $(<4 \mu \mathrm{m})$, fine silts $(4-20 \mu \mathrm{m})$ and coarse silts $(20-63 \mu \mathrm{m})$. The median grain size (MGS) was recovered for each grain size distribution points.

Particulate organic and inorganic carbon (POC, PIC) contents were determined using a TOC- $\mathrm{V}_{\mathrm{CSH}}$ analyzer $\left(\right.$ Shimadzu $\left.{ }^{\circledR}\right)$, coupled with a SSM-5000A module. The total carbon content was determined using the high-temperature $\left(900^{\circ} \mathrm{C}\right)$ catalytic oxidation method with NDIR detection of $\mathrm{CO}_{2}$ (Benner and Strom, 1993), calibrated using glucose (Fisher Scientific ${ }^{\circledR}$, Analytical Reagent grade) with an accuracy of $0.1 \mathrm{mg}_{\mathrm{c}}$. The inorganic carbon content was determined after addition of $\mathrm{H}_{3} \mathrm{PO}_{4}$ (Fisher Scientific ${ }^{\circledR}$, Analytical Reagent grade, $85 \%$ ) at $200{ }^{\circ} \mathrm{C}$ followed by $\mathrm{CO}_{2}$ detection, calibrated using $\mathrm{NaHCO}_{3} / \mathrm{Na}_{2} \mathrm{CO}_{3}\left(\right.$ Shimadzu $\left.^{\circledR}\right)$ with an accuracy of $0.1 \mathrm{mg}$. Then, the organic carbon content was calculated by difference between total and inorganic carbon contents. Each sample was analyzed in triplicate, with the average standard deviation being $2.3 \%$ for total and $2.4 \%$ for inorganic contents.

Total trace metals concentrations were measured by Flame Atomic Absorption Spectrometry (Varian ${ }^{\circledR}$ model 220FS) or by Graphite Furnace Atomic Absorption Spectrometry (THERMO ELECTRON CORPORATION ${ }^{\circledR}$ FS 95 Furnace autosampler, M series AA spectrometer) depending on concentration. Trace metals concentrations were measured after optimized semi-total digestion (Aqua Regia extraction) of sediment samples: $100-500 \mathrm{mg}$ (according to sample and/or element) were accurately weighed and placed with $10 \mathrm{~mL}$ aqua regia $\left(\mathrm{HNO}_{3}: \mathrm{HCl} 1 \mathrm{~V}: 3 \mathrm{~V}\right.$, Fisher Scientific ${ }^{\circledR}$ Trace Analysis grade, $\mathrm{HNO}_{3} 70 \%-16 \mathrm{M}, \mathrm{HCl} 37 \%-12 \mathrm{M}$ ) in $50 \mathrm{~mL}$ Teflon (PTFE) bombs using a microwave oven (ANTON PAAR ${ }^{\circledR}$ Multiwave 3000) at controlled pressure and temperature (step 1: $1200 \mathrm{~W}$ power for $10 \mathrm{~min}$ - hold $40 \mathrm{~min}$; step 2: $0 \mathrm{~W}$ power for $20 \mathrm{~min}$ ). The obtained suspension was then filtered through a pre-cleaned on-line filter $(0.45 \mu \mathrm{m}$, Whatman), and diluted to $100 \mathrm{~mL}$ for analysis. Replicated measurements of certified international reference materials (PACS-2; Table 1), reagent blanks, and duplicated sediment samples were used to verify accuracy and precision.

Table 1

Results (mean \pm standard deviation) obtained from certified reference materials analysis.

\begin{tabular}{lll}
\hline & Certified value $(\mathrm{mg} / \mathrm{kg})$ & Measured value $(\mathrm{mg} / \mathrm{kg})$ \\
\hline PACS $2(n=20)$ & & \\
$\mathrm{Cu}$ & $310 \pm 12$ & $307 \pm 12$ \\
$\mathrm{~Pb}$ & $183 \pm 8$ & $173 \pm 7$ \\
$\mathrm{Zn}$ & $364 \pm 23$ & $337 \pm 10$ \\
$\mathrm{Ni}$ & $39.5 \pm 2.3$ & $37.9 \pm 3.3$ \\
$\mathrm{Cd}$ & $2.11 \pm 0.15$ & $2.27 \pm 0.21$ \\
$\mathrm{Cr}$ & $90.7 \pm 4.6$ & $71.6 \pm 2.0$ \\
$\mathrm{As}$ & $26.2 \pm 1.5$ & $25.9 \pm 1.4$ \\
MESS & $(n=20)$ & \\
$\mathrm{Hg}$ & $0.091 \pm 0.009$ & $0.087 \pm 0.005$ \\
\hline
\end{tabular}


$\mathrm{Hg}$ concentrations were determined by an Advanced Mercury Analyzer AMA 254 (LECO Corporation) on $\sim 30$ to $100 \mathrm{mg}$ of sediment sample without pre-treatment. The AMA 254 technique of direct combustion features a combustion/catalyst tube that decomposes the sample in an oxygen-rich environment and removes interfering elements. A gold amalgamator trap collects all mercury from the evolved gases, mercury is then determined by a standard atomic absorption spectrophotometer at a specific wavelength $(253.7 \mathrm{~nm})$. Replicated measurements of international reference materials (MESS-3; Table 1), blanks and duplicated sediment samples were used to access accuracy and precision.

Major elements ( $\mathrm{Al}, \mathrm{Na}, \mathrm{Mg}, \mathrm{Si}, \mathrm{Cl}, \mathrm{K}, \mathrm{Ca}, \mathrm{Ti}, \mathrm{Fe}, \mathrm{S}$ ) were measured by XRF (Philips PW $2400^{\circledR}$ ) equipped with a Rh-tube. Freeze-dried samples were previously crushed at $50 \mu \mathrm{m}$ with a carbide tungsten rings mill (NAEF model M02).

\subsection{Sedimentation rates determination}

Apparent sedimentation rates were determined applying the ${ }^{210} \mathrm{~Pb}$ dating method on high resolution core, sliced in $1 \mathrm{~cm}$ sections. Direct gamma spectrometry analyses were performed on closed volumes of $60 \mathrm{~mL}$ of dried sediment using spectrometers with low background level HPGe-detectors with a $0.5 \mathrm{~mm}$ thickness beryllium window (Bouisset and Calmet, 1997). Samples were measured for $24-48 \mathrm{~h}$. ${ }^{210} \mathrm{~Pb}$ (half-life $22.3 \mathrm{yr}$ ) was determined based on its photopeak at $661.7 \mathrm{keV}$. Self-adsorption corrections were done using in-house standards. Measurements were done after at least 4 weeks of equilibrium and therefore it was possible to estimate supported ${ }^{210} \mathrm{~Pb}$ using ${ }^{214} \mathrm{~Pb}$ activities.

Vertical distributions of the naturally occurring radionuclide ${ }^{210} \mathrm{~Pb}$ have been determined to estimate the sedimentation regime in this area. ${ }^{210} \mathrm{~Pb}$ is a member of the ${ }^{238} \mathrm{U}$ decay series and is produced in the atmosphere from the decay of ${ }^{222} \mathrm{Rn}$ emanated from continental rocks and soils. ${ }^{210} \mathrm{~Pb}$ deposited onto the sea surface is rapidly associated to settling particles and accumulates in sediments, where its vertical profile is a function of sediment accumulation rate and of its physical decay (Miralles et al., 2005; Marion et al., 2010). Because of its 22.3 year half-life, ${ }^{210} \mathrm{~Pb}$ provides indication on sedimentation occurring over the past 100 years. Apparent sediment accumulation rates were estimated from the slope of the linear regression of the logarithm ${ }^{210} \mathrm{~Pb}$ excess activity $v$. depth assuming a steady state accumulation of sediments and that the excess ${ }^{210} \mathrm{~Pb}$ activity of depositing sediment particles was constant (Appleby and Oldfield, 1992).

\section{Results and discussion}

Several approaches were used to assess the degree of contamination and the potential toxicity of the Toulon bay sediments:

- Comparison to the French limits for sediment dredging and calculation of the surface-weighted average (SWA) metal concentrations,

- Calculation of metal-enrichment factors (EF) and geoaccumulation indices (Igeo),

- Evaluation of trace element stocks,

- Principal component analysis (PCA),

- Ecotoxicological assessment of trace element using sediment quality guidelines (SQG).

Data proceeding was realized with Matlab software (6.5 version), contour map representations, used to illustrate spatial variations in the datasets, were established with Surfer software (6.04 version), and the krigging algorithm was applied as the interpolation method. The quantiles of the concentration range obtained for each element were used to define ten classes of concentration ranges to establish and compare distribution maps.

\subsection{Grain size, total organic carbon (TOC) and heavy metals distribution in surface sediment}

Results for grain size showed that fine fraction (coarse silts) was predominant over the entire bay, median grain size values (i.e. the 50th percentile of the grain size distribution) ranged between 10 and $60 \mu \mathrm{m}$, with a median value of $27 \mu \mathrm{m}$ (Table 2). Yet, for some points located near artificial beaches, the $2 \mathrm{~mm}$ fraction was significant. Sediment from Toulon bay presented a high homogeneity, and a low variability with depth. This predominance of fine fraction will promote the accumulation of contaminants in the sediment (Ujevic et al., 2000).

Total organic carbon (TOC) contents ranged between $0.3 \%$ and $7.7 \%$, with a median value of $4.2 \%$ (Table 2 ). Results obtained for inorganic carbon (TIC) ranged between $1.9 \%$ and $9.7 \%$ with median value of $3.4 \%$. Higher values of inorganic contents were located in the large bay corresponding to points with a high content of shells.

No statistically significant correlation between TOC and grain size fractions was detected, excepted for the lowest value localized in the ferry boat harbor, corresponding to the minimum of fine fraction, probably due to the effect of ferry boat traffic on sediment resuspension and subsequent fine fraction export.

The trace element contents of the entire bay are presented in the Table 2, including minimum, maximum and median values. The density of sample points (55 points on $52 \mathrm{~km}^{2}$ surface) was in the same order of magnitude than the study realized by Larrose et al. (2010) on the Gironde estuary. As in this study, the high spatial resolution maps allowed the establishment of surfaceweighted average (SWA) metal concentrations for the Toulon bay, i.e. the most representative concentration values at the entire bay scale (Table 2 ).

Obtained trace elements concentrations were also compared to the French limits ( $N 1$ and $N 2$, Table 2) concerning marine and estuarine sediment dredging (JORF No. 184, 10-08-2000). Below N1 Level, the potential impact is considered neutral or negligible; the observed values are comparable to the background values along the French costs. Between $N 1$ and N2, further investigation may be necessary; tests are then performed to assess the overall toxicity of the sediments. Above N2 Level, impact on the environment is demonstrated, and the dredged sediment is considered as a hazardous waste which must be stored in appropriate dump.

Spatial distributions obtained for cadmium, nickel and chromium showed no or weak contamination of the bay (bellow N1 limit; Table 2), neither in $0-5 \mathrm{~cm}$ nor in $5-10 \mathrm{~cm}$ slices, except in an enclosed part or the north of the small bay. The SWA content obtained for these elements, all below the $N 1$ limit, led to similar conclusions: absence of pollution for $\mathrm{Cd}, \mathrm{Cr}$ and $\mathrm{Ni}$ in the Toulon bay. For these reasons, spatial distribution maps were not represented in the present study.

Spatial distribution obtained for arsenic (Fig. 2) showed a low contamination of the small bay, where the activities are the most important. The large bay presented no contamination (under $N 1$ limit), except at two points corresponding to sewage outfalls. Distributions observed for the $5-10 \mathrm{~cm}$ slice were similar $\left(R^{2} 0.66\right)$, with an increase of $20 \%$ of the measured values, sign of higher inputs in the past. SWA obtained on the bay scale was under the $N 1$ limit indicating no contamination problem for this contaminant.

Spatial distributions (0-5 cm slice) obtained for copper, lead and zinc (Fig. 2) showed a very high contamination of the north of the small bay (up to $9 \times N 2$ for copper, Table 2 ), in the most enclosed parts, where the activities are the most important, whereas the large bay was less affected. The weak turnover of the water column in these enclosed parts also contributed to accumulated pol- 
Table 2

Characteristics of the Toulon bay $0-5 \mathrm{~cm}$ slice sediments ( $N$ : number of analysed samples; MGS: median grain size ( $\mu \mathrm{m})$; POC: particulate organic carbon (\%); SWA: surfaceweighted average trace element concentrations; N1-N2: French limits for dredging sediments; EF: minimum and maximum enrichment factor; Igeo: minimum and maximum geoaccumulation index; total trace element stock; sediment quality guidelines values: effect range-low (ERL) and effect range-median (ERM); UCC: upper continental crust composition).

\begin{tabular}{|c|c|c|c|c|c|c|c|c|c|c|c|c|}
\hline $\begin{array}{l}0-5 \mathrm{~cm} \text { slice } \\
\text { Toulon bay }\end{array}$ & $N$ & $\begin{array}{l}\text { MGS } \\
55\end{array}$ & POC & $\mathrm{Al}$ & As & $\mathrm{Cd}$ & $\mathrm{Cr}$ & $\mathrm{Cu}$ & $\mathrm{Hg}$ & $\mathrm{Ni}$ & $\mathrm{Pb}$ & $\mathrm{Zn}$ \\
\hline & Range $(\mu \mathrm{g} / \mathrm{g})$ & $\begin{array}{l}11- \\
57.3\end{array}$ & $\begin{array}{l}0.3- \\
7.7\end{array}$ & $\begin{array}{l}4860- \\
59.273\end{array}$ & $\begin{array}{l}6.7- \\
61\end{array}$ & $\begin{array}{l}0.05- \\
2.9\end{array}$ & $\begin{array}{l}8.5- \\
121\end{array}$ & $5.8-846$ & $0.03-27.3$ & $\begin{array}{l}8.8- \\
37.6\end{array}$ & $\begin{array}{l}14.9- \\
469\end{array}$ & $\begin{array}{l}24.3- \\
1340\end{array}$ \\
\hline & $\begin{array}{l}\text { Median } \\
(\mu \mathrm{g} / \mathrm{g})\end{array}$ & 27.2 & 4.25 & 36.675 & 20.6 & 0.17 & 41.3 & 60.6 & 1.6 & 24.4 & 87.3 & 142 \\
\hline & SWA $(\mu \mathrm{g} / \mathrm{g})$ & & & - & 19.6 & 0.15 & 33.7 & 59.9 & 1.9 & 20 & 73.3 & 113.8 \\
\hline & $\begin{array}{l}N 1-N 2(\mu \mathrm{g} / \\
\mathrm{g})\end{array}$ & & & - & $25-50$ & $1.2-2.4$ & $90-180$ & $45-90$ & $0.4-0.8$ & $37-74$ & $100-200$ & $276-552$ \\
\hline \multirow{2}{*}{$\begin{array}{l}\text { Normalized } \\
\text { enrichment } \\
\text { factor (EF) }\end{array}$} & $\begin{array}{l}\text { Range } \\
\text { (min-max) }\end{array}$ & & & - & - & - & - & $0.8-83.6$ & $0.8-1038$ & - & $1.1-31$ & $1.2-40.2$ \\
\hline & Median & & & - & - & - & - & 6.5 & 60.8 & - & 8 & 5.2 \\
\hline $1.5<$ Surface $\mathrm{EF}<5$ & $\%$ & & & - & - & - & - & 37.3 & 2.2 & - & 40.5 & 61.7 \\
\hline $5<$ Surface EF $<20$ & $\%$ & & & - & - & - & - & 54.5 & 24.7 & - & 55.9 & 29.8 \\
\hline Surface EF $>20$ & $\%$ & & & - & - & - & - & 4.7 & 72.8 & - & 1.4 & 0.7 \\
\hline \multirow[t]{2}{*}{ Igeo } & $\begin{array}{l}\text { Range } \\
\text { (min-max) }\end{array}$ & & & - & - & - & - & $\begin{array}{l}-0.8- \\
+6.4\end{array}$ & $\begin{array}{l}-0.3- \\
+9.5\end{array}$ & - & $-1-+4.6$ & $\begin{array}{l}-0.8- \\
+5.5\end{array}$ \\
\hline & Median & & & - & - & - & - & 2.7 & 5.4 & - & 2.6 & 2.5 \\
\hline $\begin{array}{l}\text { Total trace element } \\
\text { stock }(0-5 \mathrm{~cm})\end{array}$ & (ton) & & & - & - & - & - & 88 & 2.5 & - & 100 & 156 \\
\hline $\begin{array}{l}\text { Total trace element } \\
\text { stock }(0-40 \mathrm{~cm})\end{array}$ & (ton) & & & & & & & 595 & 23.1 & - & 817 & 1091 \\
\hline $\begin{array}{l}\text { Background stock } \\
\quad(0-5 \mathrm{~cm})\end{array}$ & (ton) & & & - & - & - & - & 11.3 & 0.04 & - & 22.7 & 33.4 \\
\hline Stock in the small bay & $\%$ & & & - & - & - & - & 50 & 59 & - & 44 & 53 \\
\hline ERL & $(\mu \mathrm{g} / \mathrm{g})$ & & & - & 8.2 & 1.2 & 81 & 34 & 0.15 & 20.9 & 46.7 & 150 \\
\hline ERM & $(\mu \mathrm{g} / \mathrm{g})$ & & & - & 70 & 9.6 & 370 & 270 & 0.71 & 51.6 & 218 & 410 \\
\hline ERL $<$ Surface $<$ ERM & $\%$ & & & - & 98.1 & 0.6 & 0.4 & 53.9 & 40.7 & 42.5 & 60.6 & 18.9 \\
\hline Surface $>$ ERM & $\%$ & & & - & 0 & 0 & 0 & 1.8 & 47.7 & 0 & 2.4 & 2.8 \\
\hline UCC & $(\mu \mathrm{g} / \mathrm{g})$ & & & 77.440 & 2 & 0.1 & 35 & 14.3 & 0.06 & 18.6 & 17 & 52 \\
\hline $\begin{array}{l}\text { Toulon bay } \\
\text { background } \\
(N=243)\end{array}$ & $(\mu \mathrm{g} / \mathrm{g})$ & & & 33.020 & 8.1 & 0.042 & 13 & 6.8 & 0.025 & 10.7 & 13.6 & 20 \\
\hline
\end{tabular}

lution. The SWA concentration values (ranging from $60 \mu \mathrm{g} / \mathrm{g}$ for $\mathrm{Cu}$ to $114 \mu \mathrm{g} / \mathrm{g}$ for $\mathrm{Zn}$ ) were under $N 1$ thresholds due to the much larger surface of the unpolluted large bay compared to the small bay.

Results for mercury (Fig. 2) indicated an extremely high contamination of all the small bay (until $27 \mu \mathrm{g} / \mathrm{g}$ in $0-5 \mathrm{~cm}$ slice, up to $34 \times N 2$ ) (Table 2), with an export to the large bay following the hydrodynamics of the site, similarly to $\mathrm{Cu}, \mathrm{Pb}$ and $\mathrm{Zn}$. This export led to a significant contamination of the entire bay with a SWA value close to $2 \mu \mathrm{g} / \mathrm{g}(2.5 \times N 2)$. To our knowledge, an as high and extended $\mathrm{Hg}$ contamination has never been encountered in the literature for comparable marine environments (Bothner et al., 1998; Casado-Martínez et al., 2006; McCready et al., 2006; Sprovieri et al., 2007; Clark and Benoit., 2009; Renzi et al., 2009, 2011).

The hotspot that appeared for all the contaminants in SE of "St. Mandrier" (Fig. 2) corresponds to a zone of sediment clapping, used in the 1980s for dredged contaminated sediment collected in the north of the small bay.

Distributions observed for the $5-10 \mathrm{~cm}$ slice were similar $\left(R^{2}\right.$ $0.89,0.81,0.90$ and 0.85 for $\mathrm{Cu}, \mathrm{Pb}, \mathrm{Zn}$ and $\mathrm{Hg}$ respectively), with an increase of measured concentrations close to $30 \%$ in the 5 $10 \mathrm{~cm}$ slice for all these contaminants, revealing historic contaminations. The improvement of environmental remediation practices could also explain the lower contamination levels in the surface sediments.

Mercury's spatial distribution in the entire bay (0-5 and 5$10 \mathrm{~cm}$ slices) was correlated to that of copper $\left(R^{2} 0.88\right)$. The same findings were observed for lead and zinc vs. copper $\left(R^{2} 0.77\right.$ and 0.79 respectively). These results, confirm the similarities in the spatial distribution of these 4 elements (Fig. 2), suggested that Toulon bay was submitted to a strong co-contamination event, which could be dated by analysis of deep cores. Different findings were obtained for arsenic which did not show any correlation with other contaminants (As vs. Cu: $R^{2} 0.4$ ), possibly suggesting a different source and/or sediment behavior.

In comparison to the SWA metal concentrations calculated for the Gironde estuary by Larrose et al. (2010), Toulon bay appeared significantly more contaminated in $\mathrm{Hg}, \mathrm{Cu}, \mathrm{Pb}$, and As with SWA concentration values of $16.7,3,1.8$, and 1.2 times higher respectively, but less impacted by $\mathrm{Cd}, \mathrm{Cr}, \mathrm{Ni}$ and $\mathrm{Zn}$.

\subsection{Surface sediment enrichment factors (EF) and geoaccumulation index (Igeo)}

To distinguish anthropogenic pollution from the natural content in sediment, enrichment factors (EF) were calculated (Hilton et al., 1985; Luoma and Rainbow, 2008), comparing the measured trace element levels to the studied area's geochemical background values. In order not to overestimate or underestimate the enrichment, geochemical normalization based on the concentration of a conservative element is commonly used. The purpose of normalization is to correct changes in the nature of sediment, which may influence contaminant distribution. Several conservative elements may be used: Al, Fe, Th, Ti, Zr (Hilton et al., 1985; Reimann and de Caritat, 2005; Larrose et al., 2010). The normalized enrichment factor (EF) is defined as the observed metal/ $\mathrm{X}$ ratio $(\mathrm{X}=\mathrm{Fe}, \mathrm{Al}, \mathrm{Th}, \mathrm{Ti}, \mathrm{Zr})$ in the sample of interest divided by the background metal/X ratio (Eq. (1)), (Hilton et al., 1985; Ergin et al., 1991; Guerra-García and García-Gómez, 2005; Cukrov et al., 2011).

$\mathrm{EF}=\frac{(\mathrm{Me} / \mathrm{X}) \text { sample }}{(\mathrm{Me} / \mathrm{X}) \text { background }}$ 

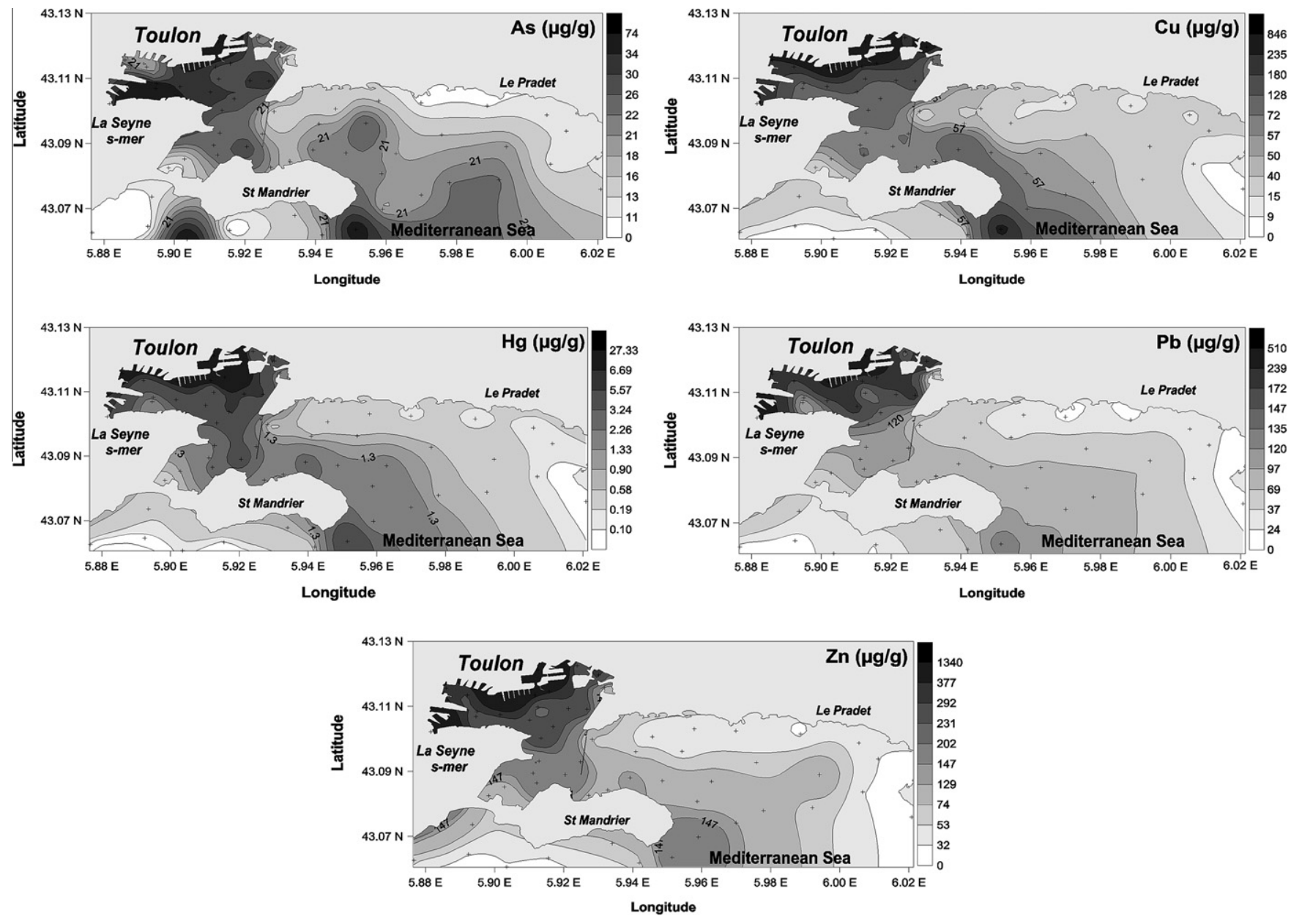

Fig. 2. Surface spatial distributions $(0-5 \mathrm{~cm})$ of $\mathrm{As}, \mathrm{Cu}, \mathrm{Hg}, \mathrm{Pb}$, and $\mathrm{Zn}(\mu \mathrm{g} / \mathrm{g})$ in the entire bay.

Five degrees of contamination are commonly defined (Sutherland, 2000):

$\mathrm{EF}<2$ : deficiency to low enrichment; $\mathrm{EF} 2-5$ : moderate enrichment; EF 5-20: significant enrichment; EF 20-40: very high enrichment; $\mathrm{EF}>$ 40: extremely high enrichment.

In this work, aluminum was chosen as the conservative element for normalization. The interest of using $\mathrm{Al}$ content is its relationship to the abundance of clay and other aluminum silicates in the sediment. Aluminum contents are influenced by natural sedimentation and the effects of enhanced erosion, but not by pollution (Li and Schoonmaker, 2003; Luoma and Rainbow, 2008). The correlation $\left(R^{2} 0.94\right)$ between $\mathrm{K}$ and $\mathrm{Al}$ concentrations in surface and deep sediment demonstrated the closed relationship between $\mathrm{Al}$ and clay minerals, thus justifying its choice for normalization.

The natural background metal/Al ratio used in the normalized EF calculation was estimated as the average of the five lowest calculated metal/Al ratios from the 243 analyzed samples (0-5 and 5$10 \mathrm{~cm}$ slices of the 55 surface samples, 5 deep cores sliced every $2 \mathrm{~cm}$ (Fig. 1)). normalized enrichment factor values for $\mathrm{Hg}, \mathrm{Cu}, \mathrm{Pb}$ and $\mathrm{Zn}$ were calculated and the EF spatial distributions for these metals in the $0-5 \mathrm{~cm}$ slice (sediment layer corresponding to 25 years of deposition, according to the measured sedimentation rate in the studied area (see Section 4.3)) is presented in Fig. 3. The other studied elements showed no contamination and so were not represented. Using these interpolated EF maps, the evaluation of the Toulon bay surface (in \%) with EF values ranging between $1.5-5,5-20$ and $>20$ was carried out.

The obtained results demonstrated that the most important enrichment factor values (up to 1000 , Table 2 ) corresponded to ex- treme mercury pollution covering almost the entire bay. These values were in the same order of magnitude as the highest recorded values for similar marine environments, demonstrating a highly diffuse contamination where $72.8 \%$ of the whole surface had an enrichment factor higher than 20 (Bothner et al., 1998; Sprovieri et al., 2007; Chen et al., 2007). Mercury EF distribution in Toulon bay clearly showed an export from small bay N-W (military enclaves) to other parts of the bay according to hydrodynamic processes of deep waters. The surface-weighted average enrichment factor calculated for the $0-5 \mathrm{~cm}$ slice in the small bay was around 180 , when it was around 64 for the entire bay. This high value for the entire bay, despite the weaker contribution of the large part opened to the sea and less affected by anthropogenic activities, also demonstrated this export from small to large bay. EF results for the $5-10 \mathrm{~cm}$ slice, corresponding to an older contamination (25-50 years ago, see Section 4.3) were correlated to the $0-5 \mathrm{~cm}$ slice $\left(R^{2} 0.85\right)$, showing similar origin and distribution, but with an increase of measured concentrations close to 30\% (maximum EF values 1500 , corresponding to $40 \mu \mathrm{g} / \mathrm{g}$ of mercury) indicating historical inputs.

This unusual contamination level of Toulon bay, the first French military harbor, could come partly from mercury fulminate used in munitions percussion caps (Arbestain et al., 2009).

Copper enrichment factors were also very important (80 at maximum (i.e. extremely high enrichment); Table 2) again corresponding to the military enclaves but also to civil harbors (Toulon and La Seyne-sur-mer; Fig 3). In the small part of the bay, the surface-weighted averaged enrichment factor calculated was around 15 (i.e. significant enrichment) whereas they reached 7 in the en- 

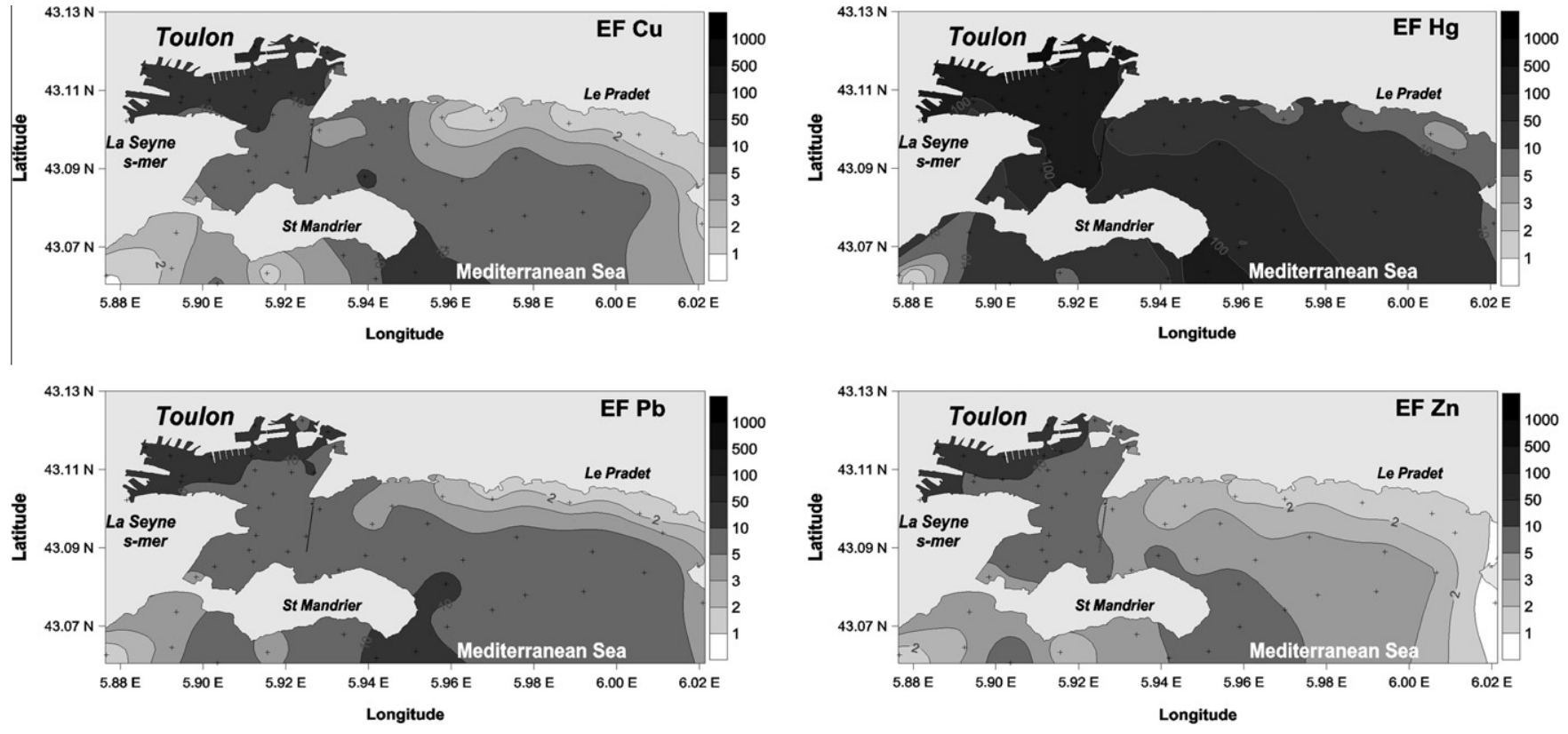

Fig. 3. ( $\mathrm{Cu}, \mathrm{Hg}, \mathrm{Pb}, \mathrm{Zn}$ ) Normalized enrichment factors ( $\mathrm{EF}$ ) spatial distributions in the $0-5 \mathrm{~cm}$ slice for the entire bay.

tire bay. Contamination could come from copper used in antifouling paints (Schiff et al., 2004; Singh and Turner, 2009; Mukherjee et al., 2009; Jones and Turner, 2010; Turner, 2010; Dafforn et al., 2011). Results obtained for the $5-10 \mathrm{~cm}$ slice showed similar origin and distribution $\left(R^{2} 0.90\right)$ with an increase of $20 \%$ of the enrichment. Improved environmental practices, with for example the establishment of sites dedicated to ships maintenance could explain this decrease in enrichment.

Concerning lead and zinc, enrichment factors ranged from important to extreme (maximal values of 40 and 31 for $\mathrm{Zn}$ and $\mathrm{Pb}$ respectively) in the small bay N-W military enclaves and civil harbors, where most of the activities focused. The large bay was less contaminated. The surface-weighted averaged enrichment factor calculated for the small bay was close to 13 and 9 for $\mathrm{Pb}$ and $\mathrm{Zn}$ respectively, whereas it was around 7 and 4.5 for the whole bay. The range of $\mathrm{EF}$ values covering the largest surface of the entire bay was between 1.5 and 5 ( (surface $=61.7 \%$ ) for $\mathrm{Zn}$ whereas it was between 5 and 20 for $\mathrm{Pb}$ (surface $=55.9 \%$ ), clearly indicating a wider contamination for $\mathrm{Pb}$. $\mathrm{Zn}$ main sources could come from its use as anode in boat hull to prevent corrosion, and antifouling paints (Mukherjee et al., 2009; Singh and Turner, 2009; Turner, 2010; Jones and Turner, 2010). Even if atmospheric particulate deposition has been demonstrated as an important $\mathrm{Pb}$ contribution to marine environment (Chester, 2000; Miralles et al., 2006), in the case of Toulon bay notably characterized by a small catchment area, this source could not be the main reason to explain the recorded levels. Instead $\mathrm{Pb}$ use in batteries and piping is the most probable source. Studying the $\mathrm{Pb}$ isotope ratio would allow confirming/infirming of this hypothesis. In the $5-10 \mathrm{~cm}$ slice, enrichment factor increased by $30 \%$, with a similar spatial distribution $\left(R^{2} 0.85\right.$ and 0.90 for $\mathrm{Pb}$ and $\mathrm{Zn}$ respectively). Compared to deeper sediments, contaminant levels measured in surface ones (signature of recent inputs) decreased, which could imply an improvement of environmental practices, due to more strict legislation. However, metal concentrations remained elevated, which probably attests the continuous export of contaminated particles from the most enclosed part to the whole bay, likely induced by sediment resuspension during extreme events (storm, large boat traffic, dredging, etc.).
In order to confirm the observations achieved by the obtained EF distributions, the geoaccumulation index (Igeo) introduced originally by Müller (1979) was used (Eq. (2)):

Igeo $=\log 2\left[\frac{C_{n}}{1.5 B_{n}}\right]$

where $C_{n}$ is the measured concentration of the considered metal ( $n$ ) in the sediment and $B_{n}$ is the geochemical background concentration of the metal $(n)$. The constant 1.5 is introduced to minimize the effect of possible variations in the background values which may be attributed to lithologic variations in the sediments.

The following classifications are given by Müller (1979) for geoaccumulation:

$\leqslant 0$ : unpolluted, $0-1$ : unpolluted to moderately polluted, $1-2$ : moderately polluted, $2-3$ : moderately to strongly polluted, $3-4$ : strongly polluted, $4-5$ : strongly to extremely polluted, $>5$ : extremely polluted. The highest class reflects at least 100 -fold enrichment above background values.

In order not to over- or under-estimate the geoaccumulation values, definition of local background values were requested. So, the five lowest values of each element on the 243 analyzed samples were averaged. In comparison to the Upper Continental Crust composition (UCC, Wedepohl 1995) Toulon bay presented lower background values (excepted for arsenic, Table 2).

Geoaccumulation index for $\mathrm{Hg}, \mathrm{Cu}, \mathrm{Pb}$, and $\mathrm{Zn}$ were calculated, with range (min. and max.) and median values are presented in the Table 2.

According to the Igeo values, $\mathrm{Hg}$ is the heaviest pollutant among the measured elements in Toulon bay, with values as high as 9.5, corresponding to an extremely polluted area, followed by $\mathrm{Cu}, \mathrm{Pb}$ and $\mathrm{Zn}$. Hg median Igeo on the entire bay (5.4) again indicated an extremely polluted area. The median Igeo were close to 2.5 for $\mathrm{Cu}, \mathrm{Pb}$ and $\mathrm{Zn}$, corresponding to a moderately to strongly polluted area. As indicated with the EF distributions, pollution seemed to come from the north of the small bay (military parts and civil harbors), where activities focused, to spread to the large bay following deep waters hydrodynamic processes. The Igeo values gradually decreased with distance from the small bay, indicating a 
contamination dilution, to reach negative Igeo values corresponding to an unpolluted area at the end of large bay opened to the sea. Similar distributions for the $5-10 \mathrm{~cm}$ slice were observed $\left(R^{2} \approx 0.85\right.$ for $\mathrm{Hg}, \mathrm{Cu}, \mathrm{Pb}$, and $\left.\mathrm{Zn}\right)$ indicating a common contamination origin.

\subsection{Historic depth profile}

Results presented in this part of the paper concern a deep sediment core collected in the small bay ( $\mathbf{\square}$, Fig. 1), at the location of an older navy submarine base. This submarine base was destroyed by bombardment in 1944, and has not been rebuilt since.

Apparent average sedimentation rate was estimated using the vertical distribution of ${ }^{210} \mathrm{~Pb}$ activity (Appleby and Oldfield, 1978; Miralles et al., 2005; MacKenzie et al., 2011) in the sediment column. Results indicated an annual average sedimentation rate of $0.21 \pm 0.05 \mathrm{~cm}$. The $10 \mathrm{~cm}$ slice on top of sediment represents 50 years of history and a $1 \mathrm{~m}$-core is equivalent to 500 years. Comparable sedimentation rates were determined for the 4 other studied high-resolution cores (data not shown), distributed in the whole of Toulon bay (closed symbols, Fig. 1), which involved a similar apparent sedimentation rate in the entire studied zone.

High resolution vertical depth profiles of $\mathrm{Al}, \mathrm{As}, \mathrm{Cu}, \mathrm{Hg}, \mathrm{Pb}$, and $\mathrm{Zn}$ contents are presented in Fig. 4. Sediment characteristics (including MGS, POC, metals contents, normalized EF and Igeo range and median values) are presented in Table 3. Measured concentrations values for $\mathrm{Cd}, \mathrm{Cr}$ and $\mathrm{Ni}$ were under the $\mathrm{N} 1$ limit so they were not presented in the present paper.

Results for grain size showed that fine fraction was predominant on the entire core, with a median value of $21.7 \mu \mathrm{m}$ (coarse silts). Total organic carbon (TOC) contents ranged between $3.8 \%$ and $6.5 \%$, with a median value of $5.1 \%$. No statistically significant correlation between TOC and grain size fractions or metal contents was detected.

Results for metals (Fig. 4 and Table 3) showed the high contamination level of this point. Metals depth profiles obtained were significantly correlated to each other $\left(\mathrm{Hg}\right.$ vs. $\mathrm{Cu} / \mathrm{Pb} / \mathrm{Zn} / \mathrm{As} ; R^{2} 0.85$, $0.90,0.98$ and 0.66 respectively) indicating a common contamination history. Unlike aluminum content, each trace element profile presented a maximum at $10 \mathrm{~cm}$-depth showing a co-contamination episode that could be attributed, with the average calculated sedimentation rate, as a consiquence of the 2nd World War. Indeed, the scuttling in November 1942 of the French navy fleet (one hundred ships destroyed and sunk, mainly in the small Toulon bay) and the subsequent wreck raising and treatment could be the main explanation of this contamination. The maximum measured values $(12.4,228,377$ and $700 \mu \mathrm{g} / \mathrm{g}$ for $\mathrm{Hg}, \mathrm{Cu}, \mathrm{Pb}$, and $\mathrm{Zn}$ respectively) exceeded the $N 2$ limits from several order of magnitude (up to 15 times $\mathrm{N} 2$ for $\mathrm{Hg}$ ), indicating a strong negative impact on the environment. Arsenic profile also presented a $10-\mathrm{cm}$ maximum with lower amplitude of contamination. This could be either due to a weaker arsenic use or to a different reactivity in sediment inducing higher remobilization. It should be noted that similar 10 -cm depth contaminants peaks (data not shown) were also observed on the 4 other deep cores studied (closed symbols, Fig. 1), proof of the pollutants dispersion following these historical events, and its extension to the whole bay probably due to association of sediment resuspension (by storm, boat traffic, etc.) and transport by deep waters hydrodynamics. Further laboratory experiments of sediment resuspension should be performed, in association to the use of hydrodynamic modeling, to assess this redistribution hypothesis.

Two other maxima were observed on each vertical profile at -40 and $-50 \mathrm{~cm}$ depths (Fig 4 ), but not on the profiles obtained for the 4 other studied sites (data not shown). With the calculated sedimentation rate, these pollutions might be dated between 200 and 250 years ago, i.e. before the industrial age. As anthropogenic inputs seemed to be improbable at these depths, the hypothesis of a deep mixing of the contaminated layer $(-10 \mathrm{~cm})$ should be considered. The scheduled study of $\mathrm{Pb}$ isotopic ratios and organic contaminants such as PCBs will confirm or refute this theory.

Contrary to the others trace metals which showed a decrease of the measured concentrations in the top layer of the core, $\mathrm{Cu}$ revealed continuous inputs due to its permanent use in antifouling paints.

Range and median values of normalized enrichment factor and Igeo for $\mathrm{Hg}, \mathrm{Cu}, \mathrm{Pb}, \mathrm{Zn}$ and As obtained for the high resolution core are summarized in Table 3. Based on the normalized EF values ob-
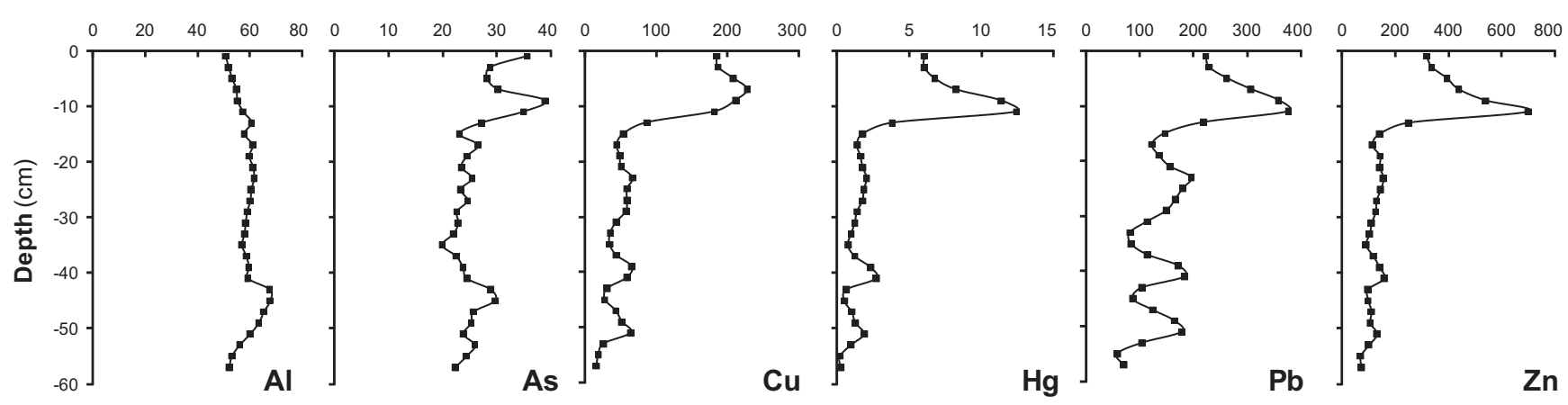

Fig. 4. Depth profiles of $\mathrm{Al}\left(\mathrm{mg} \mathrm{g}^{-1}\right)$ and $\mathrm{As}, \mathrm{Hg}, \mathrm{Cu}, \mathrm{Pb}, \mathrm{Zn}\left(\mu \mathrm{g} \mathrm{g}^{-1}\right)$ of the high resolution core $(2 \mathrm{~cm}$-slices $)$.

Table 3

Characteristics of the deep core (MGS: median grain size expressed in $\mu \mathrm{m}$; POC: particulate organic carbon expressed in \%; Range and median concentrations expressed in $\mu \mathrm{g} / \mathrm{g}$; range and median $\mathrm{EF}$ (normalized with $\mathrm{Al}$ ) and Igeo).

\begin{tabular}{|c|c|c|c|c|c|c|c|}
\hline Deep core & MGS & POC & $\mathrm{Hg}$ & $\mathrm{Cu}$ & $\mathrm{Pb}$ & $\mathrm{Zn}$ & As \\
\hline Range $(\mu \mathrm{g} / \mathrm{g})$ & $12.9-31.2$ & $3.8-6.5$ & $0.2-12.4$ & $15.9-228$ & $58-377$ & $69-700$ & $19.8-38.9$ \\
\hline Median $(\mu \mathrm{g} / \mathrm{g})$ & 21.7 & 5.1 & 1.8 & 54.4 & 156 & 31 & 24.5 \\
\hline Normalized EF (min-max) & & & $5.7-312$ & $1.1-15.6$ & $2.5-15.2$ & $1.5-13.9$ & $1.9-3.9$ \\
\hline Median & & & 42.1 & 3.5 & 5.9 & 2.5 & 2.3 \\
\hline Igeo (min-max) & & & $2.5-8.4$ & $0.6-4.5$ & $1.5-4.2$ & $1.2-4.5$ & $0.7-1.7$ \\
\hline Median & & & 5.5 & 2.4 & 2.9 & 2.1 & 1.0 \\
\hline
\end{tabular}


tained in this deep core, $\mathrm{Hg}$ is the heaviest pollutant, followed by lead, copper, zinc and arsenic.

Mercury EF profile showed an extremely high enrichment on almost all the core. The deepest part of the core still presented values corresponding to a significant enrichment at a depth not normally affected by industrial activities. This anomaly could again be explained by the probable deep mixing of the contaminated layer $(-10 \mathrm{~cm})$.

EF obtained for copper and zinc indicated a significant enrichment down to the $12-14 \mathrm{~cm}$ depth slice, representing 70 years of deposition corresponding to the improvement of industrial and nautical activities. The decrease of enrichment on top of the core $(0-4 \mathrm{~cm})$ could show the improvement of environmental practices over the past 20 years. For the remaining part, enrichment gradually decreased with depth (except for the unexplained peaks at -40 and $-50 \mathrm{~cm}$ ) from moderate to low enrichment corresponding to the natural background.

EF values for $\mathrm{Pb}$ showed similar behavior to those of $\mathrm{Cu}$ and $\mathrm{Zn}$ (Table 3). However, even if the highest value was measured for copper enrichment, the average enrichment on the entire core was higher for lead (average EF 6.7). Contributions in Pb seemed to be stronger and older with a moderate enrichment at the bottom of the core meaning that the background level was still not reached.

Results obtained for arsenic showed a constant moderate enrichment all throughout the core. The highest values were found on top of the core down to $-10 \mathrm{~cm}$ depth corresponding to the last 50 years.

According to the Igeo values $\mathrm{Hg}$ is the heaviest pollutant among the measured elements on the high resolution core, followed by $\mathrm{Pb}$, $\mathrm{Cu}, \mathrm{Zn}$ and As. The obtained results (depth profile, maximal values, etc.) led to the same conclusions as the normalized EF.

\subsection{Heavy metal stocks in sediment}

Considering the extent of surface sediments contamination and the history of contaminant inputs in the studied zone, it was intended to estimate the contaminants stock. Based on the metals contents in the surface sediment, taking into account the density of wet sediment and the depth of the analyzed slice, the trace element stocks in the $0-5 \mathrm{~cm}$ slice were estimated in the surface sediment $\left(S_{i}\right.$, Eq. (3)) of the entire Toulon bay, as follows:

$S_{i}=\int_{x, y \min }^{x, y \max }(\Delta x \times \Delta y) \times \Delta Z \times d \times\left(C_{x, y}^{i}-C_{b}^{i}\right)$

where $S_{i}$ is the trace element stock (in ton) in the $0-5 \mathrm{~cm}$ layer, $(\Delta z=0.05 \mathrm{~m}), \Delta x$ and $\Delta y$ are length and width of the mesh grid, $d$ is the density of the wet sediment $(d=0.64 \mathrm{t}$ dry sediment for $1 \mathrm{~m}^{3}$ of wet sediment), $C_{x, y}^{i}$ is the mean trace element concentration in the surface unit obtained from the interpolated dataset, and $C_{b}^{i}$ the mean background values.

Same calculation could be performed with results from the 5$10 \mathrm{~cm}$ slice, leading to the calculation of contaminant stock, at the scale of the Toulon bay, in the first $10 \mathrm{~cm}$ of surface sediments. Considering the shape of contaminant depth profiles recorded on deep core (Fig. 4), it appeared obvious that contamination is not limited to the first $10 \mathrm{~cm}$, so a correct evaluation of contaminant stock must include subjacent layers, at least down to $40 \mathrm{~cm}$. Using the obtained data, an evaluation of the global contaminant stock (i.e. $0-40 \mathrm{~cm}$ ) can be made by finding a relationship between contaminant level of the top layer, recorded at high spatial resolution for the whole studied zone, and the contaminant depth profile, recorded at high resolution for a restricted number of sampling points. As depicted in the part 4.3. (Fig. 4), the contaminant depth profiles showed strong similarities, implying similar history of contamination. Same findings were obtained when comparing the data collected from the 4 other studied high resolution cores (data not shown), distributed in the whole of Toulon bay (closed symbols, Fig. 1). Fig. 5 shows the $\mathrm{Cu}, \mathrm{Hg}, \mathrm{Pb}$ and $\mathrm{Zn}$ contaminant content in the first $40 \mathrm{~cm}$ for the 5 studied high resolution cores vs. the content of the first $10 \mathrm{~cm}$, after normalization to the sediment height. As the correlation obtained was significant $\left(R^{2} 0.96\right)$, the mathematical equation linking $0-40 \mathrm{~cm}$ and $0-10 \mathrm{~cm}$ contaminant contents was then used to estimate the global contaminant stock $(0-40 \mathrm{~cm})$ at the whole Toulon bay scale from the sum of $0-5$ and $5-10 \mathrm{~cm}$ ones previously calculated using Eq. (3).

The obtained results for heavy metal stocks in the $0-5 \mathrm{~cm}$ sediment layer of Toulon bay (Table 2) ranged from $3 \mathrm{t}(\mathrm{Hg})$ to $162 \mathrm{t}$ $(\mathrm{Zn})$. In comparison to the background stock $(0-5 \mathrm{~cm})$, and according to the $\mathrm{EF}$ results, $\mathrm{Hg}$ presented the heaviest stock enrichment (61 times), then $\mathrm{Cu}$ (8.8 times), $\mathrm{Zn}$ (5.7 times) and $\mathrm{Pb}$ (5.4 times). The distribution of these metal stocks confirmed that the contamination comes from the small bay, with values ranging from $59 \%$ of total $\mathrm{Hg}$ content to $44 \%$ of total $\mathrm{Pb}$ content located in the small bay. This data, compared to the surfaces of the small and the large bay, 9.8 against $42.2 \mathrm{~km}^{2}$, clearly showed the very high contamination of the small bay. The localization of activities (big urban area; military arsenal; military, commercial and touristic harbors; former shipyard), and the morphology (semi-closed area, low tide and current) explain this important contamination of the small bay. The large part, less affected by anthropogenic activities and opened to the sea was more preserved from pollution.

Results obtained for the $0-40 \mathrm{~cm}$ estimated stock ranged from $1209 \mathrm{t}(\mathrm{Zn})$ to $26 \mathrm{t}(\mathrm{Hg})$, the same conclusions than for $0-5 \mathrm{~cm}$ stocks could be drawn, which demonstrated again the common origin and history of deposition for these metals.

This data will be useful for the adoption of procedures in a case of a future dredging to maintain harbor functionality. Indeed, removal of contaminated sediments is known to have negative effects on marine ecosystems due to remobilization processes (Bloom and Lasorsa, 1999; Saulnier and Mucci, 2000; Zoumis et al., 2001; Kim et al., 2006; Tankere-Muller et al., 2007; Hedge et al., 2009; Kalnejais et al., 2010). The knowledge of metal contents and stocks repartition will indicate the necessary precautions

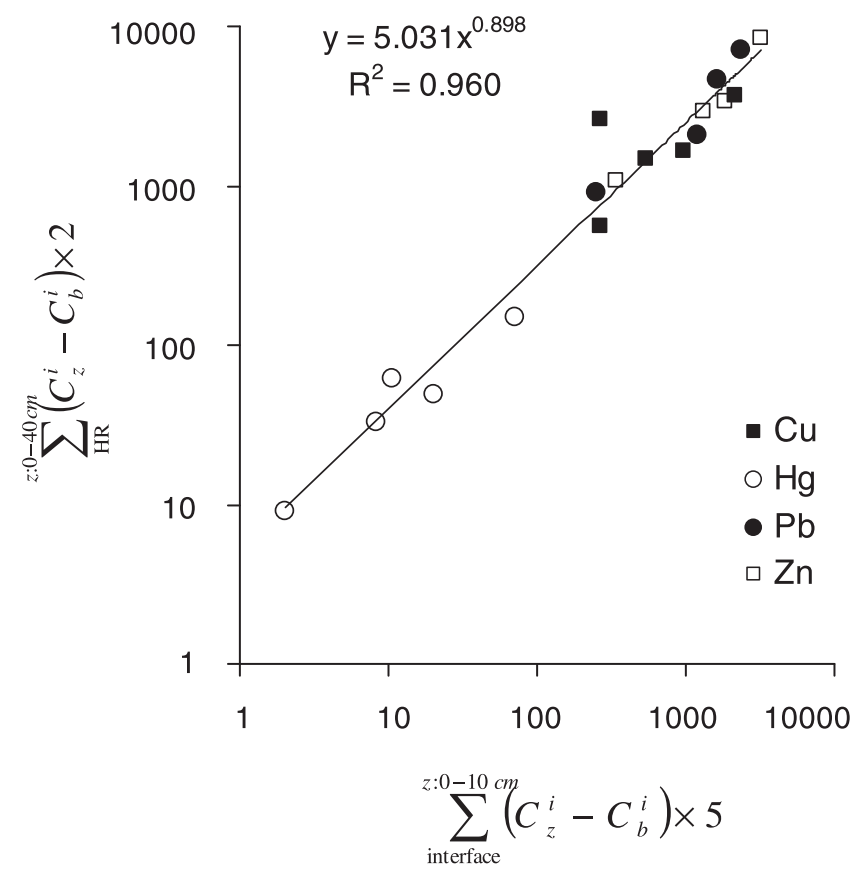

Fig. 5. Relationship between $\mathrm{Cu}, \mathrm{Hg}, \mathrm{Pb}$ and $\mathrm{Zn}$ contents in the $0-40 \mathrm{~cm}$ vs contaminant contents in the $0-10 \mathrm{~cm}$ for the 5 studied high resolution cores. 
for the realization of safe dredging and sediment storage in order to preserve the surrounding environment.

\subsection{Statistical analysis: $P C A$}

A principal component analysis was applied to the obtained data-set in order to determine correlations in the behavior of analyzed sampling points (Fig. 6). The PCA procedure allows an easy visualization of the relationships existing amongst the variables in large data sets (Kähkönen et al., 1997; Idris, 2008; Davis et al., 2009; Reid and Spencer, 2009; Passos et al., 2010). PCA treatment was performed using Matlab software. The correlation matrix of the $0-5 \mathrm{~cm}$ slice composition is presented in Table 4 .

The PCA procedure used the different sample points ( 55 points) as objects, and the measured metals concentrations $(\mathrm{Hg}, \mathrm{As}, \mathrm{Cu}, \mathrm{Zn}$, $\mathrm{Pb}, \mathrm{Al}, \mathrm{Fe}, \mathrm{Na}, \mathrm{Si}, \mathrm{Ca}, \mathrm{V}, \mathrm{K}$ ) and median grain size values as variables. Two principal components were extracted, together explaining $79.46 \%$ of the total variance (PC1: $54.60 \%$; PC2: $24.86 \%$ ). The variable straight lines, representing the projections of initial axis in the principal plane, provide information on objects comportment.

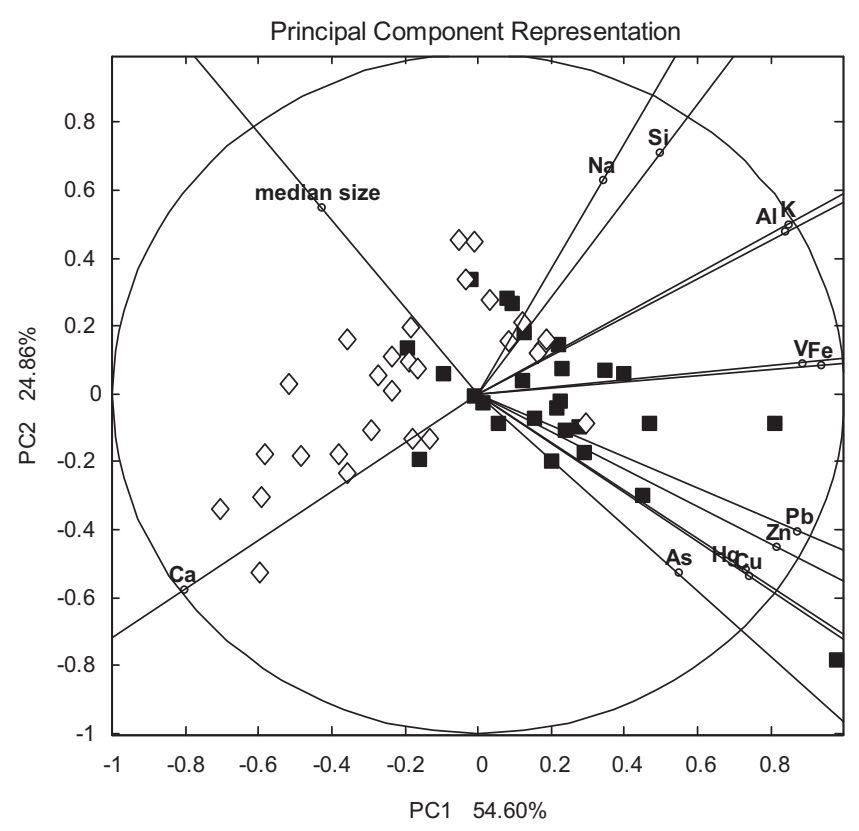

Fig. 6. Principal component analysis representation for $\mathrm{Hg}, \mathrm{As}, \mathrm{Cu}, \mathrm{Zn}, \mathrm{Pb}, \mathrm{Al}, \mathrm{Fe}, \mathrm{Na}$, $\mathrm{Si}, \mathrm{Ca}, \mathrm{V}, \mathrm{K}$ contents and median grain size of the $0-5 \mathrm{~cm}$ sampled sediments of the Toulon bay. The points located in the small bay are represented by a closed square and the points located in the large bay are represented by an open diamond.
From the PCA representation (Fig. 6) an obvious segregation appeared between the points corresponding to the large (open diamonds) and small bay (closed squares). The points located in the large bay (and some unpolluted points of the small) seemed to be linked to the natural composition of sediment. Indeed the negative-correlation between $\mathrm{Ca}$ and $\mathrm{Al}(R-0.94$, Table 4$)$ displayed an axis which separated in two parts the PCA representation, explaining the comportment of the Toulon bay sampled points. The large bay points were distributed accordingly to their $\mathrm{Ca}$ or $\mathrm{Al}$ (and $\mathrm{K}$ ) natural contents. The negative-correlation between $\mathrm{Ca}$ and $\mathrm{Al}$ (or $\mathrm{K}$ ) could be explained by the different natural origins of these elements, Ca mainly of marine origin in contrast to $\mathrm{Al}$ (or $\mathrm{K}$ ) of terrestrial origin (clay components) (Fütterer, 2006). Small bay points are linked to the heavy metals contents, materialized by the evolution of the points cloud to the variable straight lines of these metals. Moreover the good correlations between heavy metals contents $(\mathrm{Hg}, \mathrm{Cu}, \mathrm{Pb}, \mathrm{Zn}$, and As; Table 4), materialized by the close positions of corresponding straight lines, clearly show the multicontamination of the small bay sediments.

Median grain size representation appeared orthogonal to the $\mathrm{Ca}-\mathrm{Al}$ straight lines, and in opposition to the heavy metals straight lines, which indicated the absence of relation of this parameter with the others, confirmed by the correlation values (Table 4). Positions of Fe and $V$ in the PCA representation can be explained by the natural origin of these elements (crustal origin), with some points presenting an anthropogenic enrichment (Fe-V use in steel).

\subsection{Ecotoxicological assessment of trace metals in the Toulon bay sediment}

The determination of total metal concentrations in sediment is the first step to evaluate the contamination of a marine ecosystem. However it does not provide information on the potential toxicity for organisms living in or near this compartment. For this purpose, several sediment quality guidelines (SQGs) have been developed (Burton, 2002) to predict biological effects on benthic organisms. The most commonly used is the one proposed by Long et al. (1995). Using ecotoxicological data from US Coast, these authors have defined two thresholds: the effects-range-low (ERL) and the effects-range-median (ERM), respectively representing the 10th and the 50th percentiles of the effect dataset. ERL corresponds to the concentrations limit for each contaminant from which negative effects on biota could appear, and ERM corresponds to the concentrations limit from which significant adverse effects on biota are expected. ERL and ERM values for each contaminant, and the corresponding surfaces of the Toulon bay between these values and above ERM values were reported in Table 2 .

It appeared clearly that mercury was the principal contaminant in terms of toxicity for marine organisms, with $47.7 \%$ of the whole

Table 4

Correlation matrix $(R)$ of surface sediment $(0-5 \mathrm{~cm})$ element concentrations and median grain size in the Toulon bay.

\begin{tabular}{|c|c|c|c|c|c|c|c|c|c|c|c|c|c|}
\hline$R$ & $\mathrm{Hg}$ & As & $\mathrm{Cu}$ & $\mathrm{Zn}$ & $\mathrm{Pb}$ & $\mathrm{Al}$ & $\mathrm{Fe}$ & $\mathrm{Na}$ & $\mathrm{Si}$ & $\mathrm{Ca}$ & $\mathrm{V}$ & $\mathrm{K}$ & MGS \\
\hline $\mathrm{Hg}$ & 1 & & & & & & & & & & & & \\
\hline As & 0.58 & 1 & & & & & & & & & & & \\
\hline $\mathrm{Cu}$ & 0.94 & 0.61 & 1 & & & & & & & & & & \\
\hline $\mathrm{Zn}$ & 0.85 & 0.60 & 0.89 & 1 & & & & & & & & & \\
\hline $\mathrm{Pb}$ & 0.83 & 0.61 & 0.88 & 0.95 & 1 & & & & & & & & \\
\hline $\mathrm{Al}$ & 0.34 & 0.17 & 0.34 & 0.46 & 0.54 & 1 & & & & & & & \\
\hline $\mathrm{Fe}$ & 0.57 & 0.49 & 0.57 & 0.68 & 0.77 & 0.88 & 1 & & & & & & \\
\hline $\mathrm{Na}$ & 0.03 & -0.07 & 0.01 & 0.03 & 0.06 & 0.48 & 0.23 & 1 & & & & & \\
\hline $\mathrm{Si}$ & 0.00 & -0.11 & 0.03 & 0.11 & 0.14 & 0.75 & 0.51 & 0.46 & 1 & & & & \\
\hline $\mathrm{Ca}$ & -0.29 & -0.16 & -0.29 & -0.39 & -0.46 & -0.94 & -0.79 & -0.65 & -0.84 & 1 & & & \\
\hline V & 0.56 & 0.48 & 0.52 & 0.61 & 0.71 & 0.78 & 0.88 & 0.36 & 0.39 & -0.75 & 1 & & \\
\hline K & 0.33 & 0.18 & 0.33 & 0.45 & 0.54 & 0.98 & 0.86 & 0.56 & 0.75 & -0.96 & 0.81 & 1 & \\
\hline MGS & -0.44 & -0.48 & -0.46 & -0.48 & -0.57 & -0.14 & -0.41 & 0.32 & 0.13 & 0.06 & -0.35 & -0.14 & 1 \\
\hline
\end{tabular}


surface presenting values higher than ERM (Table 2), followed by $\mathrm{Zn}(2.85 \%), \mathrm{Pb}(2.45 \%)$ and $\mathrm{Cu}$ (1.79\%). The other studied elements presented no values exceeding ERM. The mercury contamination, according to the EF and Igeo data (see Section 4.2), indicated $88.5 \%$ of the surface with values higher than ERL which means that almost all the sediments of the bay could have harmful effects on benthic organisms. In comparison to the ERL concentrations, the Toulon bay sediment presented a potential toxicity risk for As, $\mathrm{Ni}, \mathrm{Cu}, \mathrm{Pb}$ and $\mathrm{Zn}$, with values between $98 \%$ and $18.9 \%$ of the surface above the ERL limit.

In order to estimate the effects of a multiple pollution, which is often encountered in natural environments affected by human activities, mean-ERM-quotient (m-ERM-Q) were calculated according to Long et al. (1998):

$m-\mathrm{ERM}-Q=\frac{\sum_{i=1}^{n}\left(C_{i} / \mathrm{ERM}_{i}\right)}{n}$

where $C_{i}$ is the sediment concentration of compound $i$, ERMi is the ERM for compound $(i)$ and $n$ is the number of compounds.

From the ecotoxicological dataset obtained for the US Coasts, Long et al. (1998) have defined several classes of toxicity probability for biota: $\mathrm{m}$-ERM-Q $<0.1$ has a $9 \%$ probability of being toxic (based on amphipod survival test); $\mathrm{m}$-ERM-Q between $0.11 \%$ and $0.5 \%$ has $21 \%$ probability of toxicity; m-ERM-Q between 0.51 and 1.5 has a probability of $49 \%$ to be toxic; and $\mathrm{m}-\mathrm{ERM}-\mathrm{Q}>1.50$ has $76 \%$ probability of toxicity.

Using the concentrations of the eight studied contaminants ( $n=8$; As, $\mathrm{Cd}, \mathrm{Cr}, \mathrm{Cu}, \mathrm{Hg}, \mathrm{Ni}, \mathrm{Pb}$, and $\mathrm{Zn}$ ) the m-ERM-quotients were calculated and the obtained distribution in Toulon bay is presented in Fig. 7. The m-ERM-Q distribution showed that almost all the north of the small bay presented values higher than 1.5 , which meant a $76 \%$ probability of toxicity. In the most enclosed parts, the $\mathrm{m}-\mathrm{ERM}-\mathrm{Q}$ reached values as high as 5 (probability of toxicity above $90 \%$, Long et al. (1998)), i.e. indicating an obvious toxic risk. The $\mathrm{m}-\mathrm{ERM}-\mathrm{Q}$ distribution in the entire bay clearly showed the export following the hydrodynamic shifts of the contamination and by consequence the ecotoxicological risk. The sea-wall presence created a channel of deposit confirmed by the m-ERM-Q values. As previously explained, the hotspot in SE of "St. Mandrier" corresponds to a zone of sediment clapping, used in the 1980s for dredged contaminated sediment collected in the north of the small bay. The m-ERM-Q in this zone, between 1 and 2 (49\%-76\% probability of toxicity), proved the negative impact of dredged contaminated sediments deposit on the ecosystem.

In the south of the small bay, between "La Seyne s-mer" and "St. Mandrier" (Fig. 7), which is a shallow zone with low water regeneration, fish and mussels farms are present. In this area, m-ERM-Q values ranged between 0.2 and 0.5 , so indicating sediment with $21 \%$ probability of toxicity. The impact of contaminated sediment on the water column due to resuspension and remobilization processes have already been demonstrated (Saulnier and Mucci, 2000; Zoumis et al., 2001; Kim et al., 2006; Tankere-Muller et al., 2007;

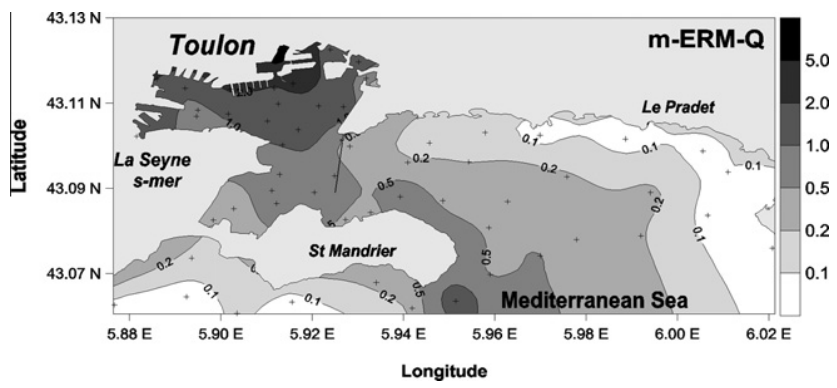

Fig. 7. Spatial distribution of mean-ERM-quotient values for the surface sediment $(0-5 \mathrm{~cm})$ of the entire Toulon bay.
Kalnejais et al., 2010). The m-ERM-Q obtained for the sediments of this part of the bay showed the possible adverse effects on benthic organisms, and thus the nearby living animals by remobilization processes.

For the rest of the bay, the m-ERM-quotients decreased with increasing distance from the most contaminated zones, nevertheless almost all the bay indicated values exceeding 0.1 , which reveal at least $9 \%$ of probability to be toxic for marine organisms.

This first study of sediment toxicity spatial distribution clearly showed the high contamination of the Toulon bay, and the environmental issues arising from the management of this area.

Obviously, study of other pollutants (such as PAH, PCB and TBT.) will be engaged to obtain a complete overview of the contamination state of Toulon bay. Considering the dramatic Hg contamination state of this area, additional studies must be performed to determine its speciation in sediment (methylmercury species particularly). Furthermore, contaminant dynamic in the sediment matrix and at the water/sediment interface must be studied to correctly apprehend the contaminants main pathway to the water column and biota, associated to ecotoxicological studies on various organisms, notably benthic.

\section{Conclusion}

In this study, for the first time, the metal concentrations in surface sediments $(0-5$ and $5-10 \mathrm{~cm})$ of Toulon bay were investigated. The data obtained allowed the production of very fine resolution cartography (55 sampling points for $52 \mathrm{~km}^{2}$ surface) characterizing recent anthropogenic inputs. Depth contaminant profiles were also examined to apprehend the historical inputs in the bay and to evaluate an average annual sedimentation rate $(0.21 \pm 0.05 \mathrm{~cm}$ per year).

These high resolution maps allowed the calculation of surfaceweighted-average (SWA) trace element concentrations and an estimation of the metal stocks $(0-5$ and $0-40 \mathrm{~cm})$ present in Toulon bay. In order to distinguish anthropogenic pollution from natural content in sediment, enrichment factors (EF) and Igeo index were calculated. A principal component analysis was applied to the obtained data-set to determine correlations in the behavior of analyzed sampling points. The potential risk on benthic organisms has been estimated using sediment quality guidelines values.

The obtained results demonstrated the high sediment contamination of Toulon bay, mainly in the small part where the activities focused. Mercury appeared to be the most problematic contaminant (EF as high as 1500) with levels in order of magnitude of the most polluted zone recorded all over the world in marine environments, and with a large pollution dispersion in the whole bay. The north of the small bay revealed an extreme contamination in $\mathrm{Hg}, \mathrm{Cu}, \mathrm{Pb}$, and $\mathrm{Zn}$. The distribution of the contamination has shown an export from the small part to the large part governed by hydrodynamics, most probably due to sediment resuspension processes (large boat traffic, storm, dredging, etc.). The historical depth profiles indicated a common contamination history for As, $\mathrm{Cu}, \mathrm{Hg}, \mathrm{Pb}$ and $\mathrm{Zn}$, with the same maximum at a depth probably corresponding to the scuttling of the major part of the French navy fleet during the 2nd World War and subsequent wreck raising and treatment.

In terms of heavy metals stocks, and in comparison to the natural contents, mercury enrichment was the most important, followed by $\mathrm{Cu}, \mathrm{Zn}$ and $\mathrm{Pb}$ respectively. The obtained distribution has revealed that the contamination mainly came from the small bay.

The principal component analysis (PCA) clearly demonstrated the segregation between points located in the small bay (grouped by anthropogenic metal contents) compared to those in the large bay (grouped by natural sediment composition). 
For the first time in Toulon bay, the potential toxicity of metal concentrations in sediment was evaluated by comparison with the sediment quality guidelines values (Long et al., 1995). Results revealed that almost all the entire bay is affected with toxicological risks for benthic organisms, with a strong increase of probability in the small part.

This work represents a significant database on the quality of surface sediments of the Toulon bay, as well as information on the metallic levels expected in depth. It will be useful for managers of the marine environment by allowing them to better apprehend the future maintenance required for the correct functioning of the harbor.

\section{Acknowledgments}

The authors would like to thank the French Navy for logistical support, D. François, G. Tua, G. Durrieu and B. Oursel for their participation in sampling campaigns, the French Navy scuba-divers, P. Paga and Dr. C. Lepoupon for their help in samples preparation, the LASEM-Cherbourg for participation in total metal measurements. The authors would also like to thank Dr. D. Cossa for assistance in $\mathrm{Hg}$ measurements performed at the Ifremer-Méditerranée laboratory, Pr. H.-R. Pfeifer and J.-C. Lavanchy (CAM laboratory, IMG, Lausanne University) for XRF analysis, and K.B. Gibbon-Walsh for english corrections. This collaborative work and E. Tessier Ph.D. were financially supported by the "Région PACA", "Toulon-Provence-Méditerranée (TPM)", and "l'Agence de l'Eau Rhône-Méditerranée et Corse" gathered within the CARTOCHIM program.

\section{References}

Anonymous, 2000. Directive of the European Parliament and of the Council (2000/ 60/EC) Establishing a Framework of Community Action in the Field of Water Policy, 23 October, 2000.

Appleby, P.G., Oldfield, F., 1978. The calculation of lead-210 dates assuming a constant rate of supply of unsupported ${ }^{210} \mathrm{~Pb}$ to the sediment. CATENA $5,1-8$.

Appleby P.G., Oldfield F., 1992. Application of ${ }^{210} \mathrm{~Pb}$ to sedimentation studies, in: Ivanovich, M., Harmon, R.S. (Eds.), Uranium-series Disequilibrium: Application to Earth, Marine, and Environmental Sciences, second ed., Chap. 21. Clarendon Press, Oxford, pp. 731-778.

Arbestain, M.C., Rodriguez-Lado M., Bao M., Macias M., 2009. Assessment of Mercury-Polluted Soils Adjacent to an Old Mercury-Fulminate Production Plant. Applied and Environmental Soil Science. 10.1155/2009/387419.

Benner, R., Strom, M., 1993. A critical evaluation of the analytical blank associated with DOC measurements by high-temperature catalytic oxidation. Mar. Chem. $41,153-160$

Bertolotto, R.M., Tortarolo, B., Frignani, M., Bellucci, L.G., Albanese, S., Cuneo, C., Alvarado-Aguilar, D., Picca, M.R., Gollo, E., 2005. Heavy metals in surficial coastal sediments of the Ligurian Sea. Mar. Pollut. Bull. 50, 348-356.

Bloom, N.S., Lasorsa, B.K., 1999. Changes in mercury speciation and the release of methyl mercury as a result of marine sediment dredging activities. Sci. Total Environ. 237-238, 379-385.

Bothner, M.H., Buchholtz ten Brink, M., Manheim, F.T., 1998. Metal concentrations in surface sediments of Boston harbor-Changes with time. Mar. Environ. Res. 45, 127-155.

Bouisset P. and Calmet D., 1997. Hyper Pure gamma-ray spectrometry applied to low-level environmental sample measurement, in: International Workshop on the Status of Measurement Techniques for the Identification of Nuclear Signatures, Geel, pp. 73-81.

Buccolieri, A., Buccolieri, G., Cardellicchio, N., Dell'Atti, A., Di Leo, A., Maci, A., 2006. Heavy metals in marine sediments of Taranto Gulf (Ionian Sea, Southern Italy). Mar. Chem. 99, 227-235.

Burton, J.G.A., 2002. Sediment quality criteria in use around the world. Limnology 3 , $65-76$.

Casado-Martínez, M.C., Buceta, J.L., Belzunce, M.J., DelValls, T.A., 2006. Using sediment quality guidelines for dredged material management in commercial ports from Spain. Environ. Int. 32, 388-396.

Chen, C.W., Kao, C.M., Chen, C.F., Dong, C.D., 2007. Distribution and accumulation of heavy metals in the sediments of Kaohsiung Harbor, Taiwan. Chemosphere 66, $1431-1440$.

Chester, R., 2000. Marine Geochemistry, second ed. Blackwell Science Ltd, Oxford.

Clark, H.F., Benoit, G., 2009. Current and historic mercury deposition to New Haven Harbor (CT, USA): Implications for industrial coastal environments. Sci. Total Env. 407, 4472-4479.
Cosma, B., Drago, M., Piccazzo, M., Scarponi, G., Tucci, S., 1979. Heavy metals in Ligurian Sea Sediments: distribution of $\mathrm{Cr}, \mathrm{Cu}, \mathrm{Ni}$, and $\mathrm{Mn}$ in Superficial Sediments. Mar. Chem. 8, 125-142.

Cukrov, N., Franciskovic-Bilinski, S., Hlaca, B., Barisic, D., 2011. A recent history of metal accumulation in the sediments of Rijeka harbor, Adriatic Sea. Croatia. Mar. Pollut. Bull. 62, 154-167.

Dafforn, K.A., Lewis, J.A., Johnston, E.L., 2011. Antifouling strategies: history and regulation, ecological impacts and mitigation. Mar. Pollut. Bull. 62, 453-465.

Davis, H.T., Marjorie, A.C., McDermott, S., Lawson, A.B., 2009. Identifying natural and anthropogenic sources of metals in urban and rural soils using GIS-based data, PCA, and spatial interpolation. Environ. Pollut. 157, 2378-2385.

Ergin, M., Saydam, C., Bastürk, Ö., Erdem, E., Yörük, R., 1991. Heavy metal concentrations in surface sediments from the two coastal inlets (Golden Horn Estuary and Izmit Bay) of the northeastern Sea of Marmara. Chem. Geol. 91, 269-285.

Fütterer, D.K., 2006. The Solid Phase of Marine Sediments. Marine Geochemistry. pp. $1-25$.

Guerra-García, J.M., García-Gómez, J.C., 2005. Assessing pollution levels in sediments of a harbour with two opposing entrances. Environmental implications. J. Environ. Manage. 77, 1-11.

Hedge, L.H., Knott, N.A., Johnston, E.L., 2009. Dredging related metal bioaccumulation in oysters. Mar. Pollut. Bull. 58, 832-840.

Hilton, J., Davison, W., Ochsenbein, U., 1985. A mathematical model for analysis of sediment core data: implications for enrichment factor calculations and tracemetal transport mechanisms. Chem. Geol. 48, 281-291.

Idris, A.M., 2008. Combining multivariate analysis and geochemical approaches for assessing heavy metal level in sediments from Sudanese harbors along the Red Sea coast. Microchem. J. 90, 159-163.

Ji, Y., Feng, Y., Wu, J., Zhu, T., Bai, Z., Duan, C., 2008. Using geoaccumulation index to study source profiles of soil dust in China. J. Environ. Sci. 20, 571-578.

Jones, D.E., Turner, A., 2010. Bioaccessibility and mobilisation of copper and zinc in estuarine sediment contaminated by antifouling paint particles. Estuar. Coast. Shelf S. 87, 399-404.

JORF (Journal Officiel République Française), $\mathrm{n}^{\circ} 184,10-08-2000$, ministère de l'aménagement du territoire et de l'environnement.

Kähkönen, M.A., Pantsar-Kallio, M., Manninen, P.K.G., 1997. Analysing heavy metal concentrations in the different parts of Elodea canadensis and surface sediment with pca in two boreal lakes in Southern Finland. Chemosphere 35, 2645-2656.

Kalnejais, L.H., Martin, W.R., Bothner, M.H., 2010. The release of dissolved nutrients and metals from coastal sediments due to resuspension. Mar. Chem. 121, 224235.

Kennish, M.J., 2002. Environmental threats and environmental future of estuaries. Environ. Conserv. 29, 78-107.

Kim, E.H., Mason, R.P., Porter, E.T., Soulen, H.L., 2006. The impact of resuspension on sediment mercury dynamics, and methylmercury production and fate: a mesocosm study. Mar. Chem. 102, 300-315.

Larrose, A., Coynel, A., Schäfer, J., Blanc, G., Massé, L., Maneux, E., 2010. Assessing the current state of the Gironde Estuary by mapping priority contaminant distribution and risk potential in surface sediment. Appl. Geochem. 25, 19121923.

Li, Y.H., Schoonmaker J.E., 2003. Chemical Composition and Mineralogy of Marine Sediments. Treatise on Geochemistry. D.H. Heinrich and K.T. Karl. Oxford, Pergamon. pp. 1-35.

Long, E.R., MacDonald, D.D., Smith S.L Calder, F.D., 1995. Incidence of adverse biological effects within ranges of chemical concentrations in marine and estuarine sediments. Environ. Manage. 19, 81-97.

Long, E.R., Field, L.J., MacDonald, D.D., 1998. Predicting toxicity in marine sediments with numerical sediment quality guidelines. Environ. Toxicol. Chem. 17, 714727.

Luoma, S.N., Rainbow, P.S., 2008. Metals contamination in aquatic environments. Cambridge, pp. 91-103.

MacKenzie, A.B., Hardie, S.M.L., Farmer, J.G., Eades, L.J., Pulford, I.D., 2011. Analytical and sampling constraints in ${ }^{210} \mathrm{~Pb}$ dating. Sci. Total Environ. 409, 1298-1304.

Marion, C., Dufois, F., Arnaud, M., Vella, C., 2010. In situ record of sedimentary processes near the Rhône River mouth during winter events (Gulf of Lions, Mediterranean Sea). Cont. Shelf Res. 30, 1095-1107.

Martín, J., Sanchez-Cabeza, J.A., Eriksson, M., Levy, I., Miquel, J.C., 2009. Recent accumulation of trace metals in sediments at the DYFAMED site (Northwestern Mediterranean Sea). Mar. Pollut. Bull. 59, 146-153.

McCready, S., Birch, G.F., Long, E.R., 2006. Metallic and organic contaminants in sediments of Sydney Harbour, Australia and vicinity-A chemical dataset for evaluating sediment quality guidelines. Environ. Int. 32, 455-465.

Miralles, J., Radakovitch, O., Aloisi, J.C., 2005. ${ }^{210} \mathrm{~Pb}$ sedimentation rates from the Northwestern Mediterranean margin. Mar. Geol. 216, 155-167.

Miralles, J., Véron, A.J., Radakovitch, O., Deschamps, P., Tremblay, T., Hamelin, B., 2006. Atmospheric lead fallout over the last century recorded in Gulf of Lions sediments (Mediterranean Sea). Mar. Pollut. Bull. 52, 1364-1371.

Mukherjee, A., Mohan Rao, K.V., Ramesh, U.S., 2009. Predicted concentrations of biocides from antifouling paints in Visakhapatnam Harbour. J. Environ. Manage. $90,51-59$

Müller, G. 1979. Schwermetalle in den Sedimenten des Rheins-Veranderungen Seit 1971 Umschau 79, 778-783.

Passos, E.A., Alves, J.C., Dos Santos, I.S., Alves, J.P.H., Garcia, C.A.B., Spinola Costa, A., 2010. Assessment of trace metals contamination in estuarine sediments using a sequential extraction technique and principal component analysis. Microchem. J. 96, 50-57. 
Reid, M.K., Spencer, K.L., 2009. Use of principal components analysis (PCA) on estuarine sediment datasets: The effect of data pre-treatment. Environ. Pollut. $157,2275-2281$.

Reimann, C., de Caritat, P., 2005. Distinguishing between natural and anthropogenic sources for elements in the environment: regional geochemical surveys versus enrichment factors. Sci. Total Environ. 337, 91-107.

Renzi, M., Perra, G., Guerranti, C., Mariottini, M., Baroni, D., Volterrani, M., Graziosi, M., Specchiulli, A., Focardi, S., 2009. Assessment of environmental pollutants in ten southern Italy harbor sediments. Toxicol. Ind. Health $25,351-363$.

Renzi, M., Tozzi, A., Baroni, D., Focardi, S., 2011. Factors affecting the distribution of trace elements in harbour sediments. Chem. Ecol. 27, 235-250.

Saulnier, I., Mucci, A., 2000. Trace metal remobilization following the resuspension of estuarine sediments: Saguenay Fjord. Canada. Appl. Geochem. 15, 191-210.

Schiff, K., Diehl, D., Valkirs, A., 2004. Copper emissions from antifouling paint on recreational vessels. Mar. Pollut. Bull. 48, 371-377.

Singh, N., Turner, A., 2009. Leaching of copper and zinc from spent antifouling paint particles. Environ. Pollut. 157, 371-376.
Sprovieri, M., Feo, M.L., Prevedello, L., Manta, D.S., Sammartino, S., Tamburrino, S. Marsella, E., 2007. Heavy metals, polycyclic aromatic hydrocarbons and polychlorinated biphenyls in surface sediments of the Naples harbour (southern Italy). Chemosphere 67, 998-1009.

Sutherland, R.A., 2000. Bed sediment-associated trace metals in an urban stream, Oahu. Hawaii. Environ. Geol. 39, 611-627.

Tankere-Muller, S., Zhang, H., Davison, W., Finke, N., Larsen, O., Stahl, H. Glud, R.N. 2007. Fine scale remobilisation of $\mathrm{Fe}, \mathrm{Mn}, \mathrm{Co}, \mathrm{Ni}, \mathrm{Cu}$ and $\mathrm{Cd}$ in contaminated marine sediment. Mar. Chem. 106, 192-207.

Turner, A., 2010. Marine pollution from antifouling paint particles. Mar. Pollut. Bull. $60,159-171$.

Ujevic, I., Odzak, N., Baric, A., 2000. Trace metal accumulation in different grain size fractions of the sediments from a semi-enclosed bay heavily contaminated by urban and industrial wastewaters. Water Res. 34, 3055-3061.

PA, U.S.E., 2005. Predicting toxicity to Amphipods from Sediment Chemistry. EPA/ 600/R-04/030. Washington, DC.

Zoumis, T., Schmidt, A., Grigorova, L., Calmano, W., 2001. Contaminants in sediments: remobilisation and demobilisation. Sci. Total Environ. 266, 195-202. 